\title{
Decadal shoreline erosion and recovery of beaches in modified and natural estuaries
}

\author{
Thomas E. Fellowes ${ }^{1,2^{*}}$, Ana Vila-Concejo ${ }^{1,2}$, Shari L. Gallop ${ }^{3,4}$, Ryan Schosberg ${ }^{1,2}$, \\ Vincent de Staercke ${ }^{5,6}$, John L. Largier ${ }^{7,8}$
}

${ }^{1}$ Geocoastal Research Group, School of Geosciences, Faculty of Science, University of Sydney, Sydney, Australia.

${ }^{2}$ Marine Studies Institute, Faculty of Science, University of Sydney, Sydney, Australia

${ }^{3}$ School of Science, University of Waikato, Tauranga, New Zealand

${ }^{4}$ Environmental Research Institute, University of Waikato, Hamilton, New Zealand

${ }^{5}$ Geographic Information Systems Laboratory, École Polytechnique Fédérale de Lausanne, Switzerland

${ }^{6}$ Department of Earth and Environmental Sciences, Macquarie University, Sydney, Australia

${ }^{7}$ Coastal and Marine Sciences Institute, University of California Davis, Bodega Bay, United States of America

${ }^{8}$ Department of Environmental Science and Policy, University of California Davis, Davis, United States of America

This manuscript has been submitted for publication in GEOMORPHOLOGY. Please note that, despite having undergone peer-review, the manuscript has yet to be formally accepted for publication. Subsequent versions of this manuscript may have slightly different content. If accepted, the final version of the manuscript will be available via the "peer-reviewed Publication DOI' link on the right-hand side of this webpage. Pease feel free to contact the authors.

${ }^{*}$ Corresponding Author: Thomas E. Fellowes

Email: thomas.fellowes@sydney.edu.au

Postal Address: Geocoastal Research Group, Madsen Building (F09), The University of Sydney, New South Wales, 2006, Australia. 


\section{$1 \quad$ ABSTRACT}

2 Sandy beaches in estuaries and bays (BEBs) are common landforms on the coasts of

3 many major cities. They exist under a wide range of settings and their morphology is

4 controlled by their distance from the estuary/bay entrance, exposure to different types

5 of waves (e.g., ocean swells vs locally generated wind waves), proximity to flood-tide

6 delta/shoals, and anthropogenic interventions (e.g., dredging, groynes). Both swell

7 waves propagating into estuaries/bays and locally generated wind waves can erode

8 BEBs. However, more understanding of BEB storm erosion and recovery over decadal

9 timescales is needed, as they typically respond slower than open coast beaches. Here

10 we present decadal shoreline behaviours of nine BEBs from two estuarine systems in

11 SE Australia, using 76 years of aerial imagery (1941-2017). We quantify and compare

12 decadal behaviour between beaches, developing a new typology of BEBs based on

13 shoreline evolution. We identify four decadal behaviours: prograding, quasi-stable,

14 retreating and relict - and we assess the influence of flood-tide deltas, river mouths,

15 distance from the entrance, and anthropogenic interventions. Swell-exposed BEBs

16 near the entrance are quasi-stable and recover after storms at rates comparable to

17 open coast beaches (<3 years). In contrast, BEBs further from the entrance and those with less swell exposure, have slower recovery timescales (3-15 years) and are controlled by storm return timescales. Prograding BEBs are typically far from the entrance, where fluvial, tidal and wind-wave processes dominate. Whether BEBs partially recover between storms (retreating) or never recover (relict) relates to storm

22 frequency, recovery rates and proximity to sediment sinks (e.g., dredge sites, flood23 tide deltas, tidal channels). Further, some BEBs are negatively impacted by 24 anthropogenic interventions with slower recovery and/or prolonged erosion. Findings 25 will help to better understand and manage BEB shorelines in major cities. 
27 Sheltered beach; low energy beach; storm erosion; beach recovery

\section{INTRODUCTION}

Sandy beaches in estuaries and bays (BEBs) are common landforms worldwide, found in many major coastal cities. Their morphology depends on multiple factors, including sediment supply, geological setting, proximity to flood-tide deltas, swell and local wind wave exposure (Vila-Concejo et al., 2020). In some cases, anthropogenic interventions such as dredging, groynes or revetments also influence BEBs (Lowe and Kennedy, 2016). BEBs are typically considered steep and narrow, and have been traditionally classified as 'low-energy' and dominated by local wind-wave fetch and alongshore sediment transport (Nordstrom and Jackson, 2012). However, ocean swell and infra-gravity waves that propagate into estuaries, as well as tides, currents and boat wakes may also be important for BEB morphodynamics (Jackson, 1995). Although BEBs are typically at least semi-protected from ocean waves, they can still experience erosion events due to storm waves from certain directions that can enter the estuary/bay (Vila-Concejo et al., 2010). When this happens, BEBs can experience significant erosion, proportionate or greater than open coast beaches, with slow or limited post storm recovery (Gallop et al., 2020).

There is a lack of understanding of the mechanisms that control BEB recovery (Nordstrom and Jackson, 2012), and it is clear that BEBs cannot be considered as scaled-down versions of open coast beaches (Vila-Concejo et al., 2020). While it is thought that there may be insufficient wave energy to facilitate full recovery after storm erosion, BEBs would not exist without sufficient wave energy to build them (Nordstrom and Jackson, 2012). Rather, it appears that beaches typically protected from swell recover at slower rates than open coast beaches (Costas et al., 2005). Previous BEB 
51 studies have focused largely on timescales of months to a few years (Gallop et al., 52 2020; Harris et al., 2020; Vila-Concejo et al., 2010) and it is not known if BEBs can recover fully over longer timescales - or if erosion is a one-way process for some BEB settings, leading to progressive shoreline retreat (Harris et al., 2020). For example, sediments eroded from BEBs can be transported to nearshore sediment sinks, such as flood-tide deltas/shoals (Austin et al., 2018; Vila-Concejo et al., 2011; Vila-Concejo et al., 2007). In some cases these sediments can be returned to the beach (Austin et al., 2018; Jackson, 1995), but are sometimes permanently lost to the beach system. Beach sediment may be imported through alternate pathways like alongshore transport or offshore sources under certain conditions (Vila-Concejo et al., 2010).

BEBs can exhibit distinct behaviours and morphology following storms (Carrasco et al., 2012; Costas et al., 2005). For example, Eulie et al. (2017) show how backbarrier shorelines in the Albemarle-Pamlico estuary system in North Carolina (USA) have been retreating episodically due to storms since the 1950 s, at a mean rate of 0.5 m/year. And Qiao et al. (2018) describe how 50 years of reclamation of low-lying estuarine shorelines in Shanghai (China) causes unwanted erosion of adjacent BEBs and low-lying coastal areas. Meanwhile, Gallop et al (2020) show both partial and full recovery of BEBs in New South Wales (Australia) following storm erosion. These studies highlight the tendency for slow or incomplete recovery of BEBs in contrast compared to open coast beaches. It appears that a fine balance exists between the

71 frequency and severity of erosion and the rate of accretion leading to recovery.

72 Moreover, there have been few studies of the influence of the often-extensive anthropogenic modifications on BEBs. The effects of anthropogenic intervention such as dredging, reclamation, seawalls and groynes alter BEB wave climate (Nordstrom, 1992), beach planform and shoreline positions (Lowe and Kennedy, 2016) and 
sediment source/sink pathways (Austin et al., 2018). For example, Carrasco et al.

77 (2012) report decadal change to BEB shorelines in a barrier estuary in the Algarve

78 (Portugal), which eroded up to $0.22 \mathrm{~m} /$ year due to the dredging of an adjacent 79 navigation channel. Thus, changes to estuary/bay shorelines (natural or 80 anthropogenic) can pose different complex coastal management and planning 81 challenges.

82 To understand the long-term cycle of storm erosion and modal recovery for beaches 83 in modified and natural estuaries and bays, we track shorelines on nine BEBs over 84 decadal timescales. We have three objectives: (1) to develop a behavioural typology 85 of decadal BEB shoreline evolution; (2) to determine the influence of proximal 86 geomorphological features such as flood-tide deltas or river mouths, and the distance 87 of BEB from ocean entrance; and (3) to assess the role of anthropogenic interventions on decadal BEB shoreline behaviour. This understanding of the evolution of BEBs over decadal scales is critical for effective coastal management and planning.

\section{STUDY AREA}

\subsection{Climate}

\subsubsection{General wind, wave and tide conditions}

The Sydney region in SE Australia has NE prevailing winds with mean 9 am speed of

$9410.6 \mathrm{~km} / \mathrm{h}$. The region is microtidal with a mean spring tidal range of $1.25 \mathrm{~m}$ (Harley et 95 al., 2017). The wave climate is swell dominated with moderate to high wave energy that typically originates from the S-SE $\left(\theta=135^{\circ}\right)$ and is characterised by mean

97 offshore significant wave heights $\left(H_{s}\right)$ of $1.6 \mathrm{~m}$, mean periods $\left(T_{z}\right)$ of $6 \mathrm{~s}$ and peak periods of $10 \mathrm{~s}\left(T_{p}\right)$ (Shand et al., 2010). Individual storms are defined as events with $99 H_{s}>3 \mathrm{~m}\left(95^{\text {th }}\right.$ percentile $\left.H_{s}\right)$ for at least 6 hours, separated by at least 24 hours of 
100 gentle wave conditions (Shand et al., 2010). Storm clusters are groups of storms 101 separated by less than a month, following Birkemeier et al. (1999). Storms occur year102 round but are typically more common during Austral autumn and winter (April to 103 August). Storms make landfall from a range of directions (NE to S) and are produced 104 by mid-latitude cyclonic, low-pressure systems, extratropical low-pressure systems 105 (East Coast Lows, ECLs) and lows to the east of Australia (Short and Trenaman, 106 1992). ECLs are a main source of extreme beach erosion and damage to coastal 107 infrastructure on this coast (Harley et al., 2016). Storm frequency is controlled by 108 Pacific climate patterns, including El Niño Southern Oscillation, Southern Annular 109 Mode and Pacific Decadal Oscillation (Shand et al., 2010). Storm surges are typically 110 small $(<0.7 \mathrm{~m})$ due to the region's narrow continental shelf (Harley et al., 2017).

112 The Sydney region has experienced 21 major storms (wave events) between 19411132017 and of these storms (full details in Supplementary Table S1) those that eroded 114 shorelines include:

115 - Cluster of two storms in June 1950 from NE-SE with remarkable rainfall, widespread flooding and substantial coastal erosion (Australian Bureau of Meteorology, 2015).

118 - Cluster of three storms in May-June 1974 from E-NE/E-SE, considered the most erosive event in the region since measured records began and damaging coastal infrastructure. This cluster had an estimated $H_{s}>9 \mathrm{~m}$, and an Average Recurrence Interval (ARI) of 50 years (Bryant and Kidd, 1975). Erosion was recorded in the Pittwater estuary at Snapperman and Great Mackerel beaches, and in Kamay (Aboriginal name for Botany Bay) along SW-facing BEBS 
(Congwong, Currewol and Yarra Bay), damaging the newly constructed Port Botany Revetment Wall adjacent to Yarra Bay (Bryant and Kidd, 1975; Foster et al., 1975).

- Storm in December 1988 with remarkable rainfall impacted Pittwater causing substantial erosion to Great Mackerel (Cowell, 1989; Cowell and Nelson, 1991);

- Cluster of 5 ECLs in June 2007 primarily from SE caused 8 consecutive days of storm waves $\left(H_{s}>3 \mathrm{~m}\right)$ and severe coastal erosion on Sydney's open coast beaches (Harley et al., 2016), and on the BEBs at Port Stephens, $230 \mathrm{~km}$ north of Sydney (Vila-Concejo et al., 2010).

- Cluster of 3 storms in July 2011 from ESE-SE eroded beaches along the regional coast (Gallop et al., 2020).

- Slow-moving ECL in June 2016 from E-NE when the highest waves $H_{s}>6 \mathrm{~m}$ occurred during spring high tide, causing severe erosion on the open coast (Harley et al., 2017) and at Kamay and Pittwater (Gallop et al., 2020).

\subsection{Sites}

139 We focus on two estuaries in the Sydney metropolitan area in New South Wales, 140 Australia (Fig. 1a). Both contain a broad range of BEBs (Fig. 1b-g; Table 1) with a 141 variety of distances from estuary entrance, locations relative to flood-tide delta or river 142 mouth, beach orientations, exposure to swell or wind waves, geological settings and 143 anthropogenic interventions such as reclamation or groynes (Gallop et al., 2020). 


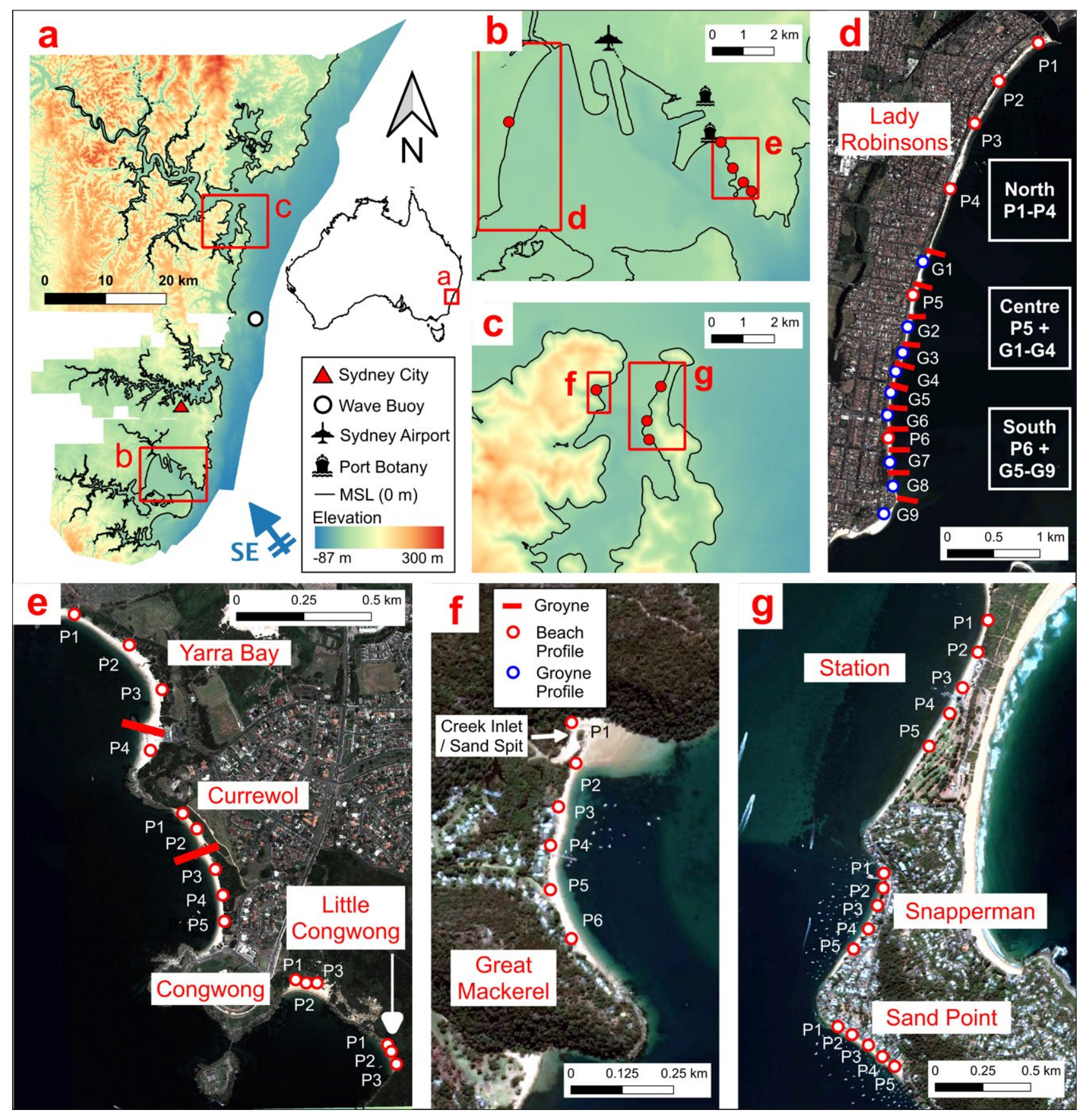

144 Figure 1. Study areas in (a) Australian and Sydney context showing (b) Kamay 145 (Botany Bay) and (c) Pittwater with the Sydney offshore Waverider buoy (black/white 146 circle). Kamay BEBs are (d) Lady Robinsons, (e) Yarra Bay, Currewol (Frenchmans), 147 Congwong and Little Congwong. Pittwater BEBs are (f) Great Mackerel, (g) Station, 148 Snapperman and Sand Point. BEBs have beach profiles (red/white circles), groyne 149 profiles (blue/white circles) and groyne locations (red lines). Digital elevation models 150 (a-c) are combined from Wilson and Power (2018a); Wilson and Power (2018b); 151 Wilson and Power (2018c) and satellite images from Google Earth. 
153 The Pittwater estuary ( $28 \mathrm{~km}$ north of Sydney) is a tide-dominated, drowned river 154 valley (Roy et al., 2001), that forms part of the Broken-Bay-Hawkesbury-River estuary 155 (Fig. 1a, c). Pittwater's entrance orientation is N-NE, and thus receives waves that 156 propagate through the estuary entrance unmodified from the NE and refracted from 157 the E-SE (Short, 1993). The estuary is $10 \mathrm{~km}$ long and $1 \mathrm{~km}$ wide and has an area of $158 \sim 18.4 \mathrm{~km}^{2}(\mathrm{OEH}, 2018)$. The mean estuary depth is $9.9 \mathrm{~m}$ and the maximum depth is $15922 \mathrm{~m}(\mathrm{OEH}, 2018)$. The sediments are primarily sandy, with a flood-tide delta that extends $\sim 2.5 \mathrm{~km}$ into the estuary. Seagrass meadows in the estuary are declining, 161 since the 1940s (Cowell and Nelson, 1991). The net southward littoral drift within 162 estuary through tidal channels along the western exposed shore and across the flood163 tide delta is estimated at $1500( \pm 300) \mathrm{m}^{3} /$ year between 1940-1990 (Kulmar and 164 Gordon, 1987).

165 Table 1: Beach locations, beach length and orientation from Short (1993), entrance 166 distance measured to the alongshore mid-beach location and beach/groyne profiles.

\begin{tabular}{|c|c|c|c|c|c|}
\hline & BEB & Orientation & $\begin{array}{c}\text { Beach } \\
\text { Length }(m)\end{array}$ & $\begin{array}{l}\text { Distance from } \\
\text { Entrance (km) }\end{array}$ & $\begin{array}{c}\text { Beach/Groyne } \\
\text { Profiles }\end{array}$ \\
\hline \multirow{4}{*}{ 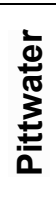 } & Great Mackerel & $E$ & 640 & 1.9 & 5 (P2-P6) \\
\hline & Station & NW & 1500 & 1.2 & 5 (P1-P5) \\
\hline & Snapperman & NW & 640 & 2.2 & 5 (P1-P5) \\
\hline & Sand Point & SW & 470 & 2.7 & 5 (P1-P5) \\
\hline \multirow{5}{*}{ 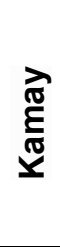 } & Yarra Bay & SW & 680 & 2.6 & 4 (P1-P4) \\
\hline & Currewol & W & 550 & 1.8 & 5 (P1-P5) \\
\hline & Congwong & SE & 160 & 1.3 & 3 (P1-P3) \\
\hline & Little Congwong & SW & 130 & 1.2 & 3 (P1-P3) \\
\hline & Lady Robinsons & $E$ & 5500 & 8.2 & 15 (P1-P6; G1-G9) \\
\hline
\end{tabular}

167 We study 4 BEBs in the Pittwater estuary (Fig. 1c, f-g; Table 1). The embayed Great 168 Mackerel Beach on the western shore is swash aligned and adjacent to the flood-tide 169 delta and exposed to NE swell waves (Fig. 1f). It has a creek inlet (behind P2) that 170 was artificially moved $100 \mathrm{~m}$ towards the northern headland in the late $1980 \mathrm{~s}$ to protect 
171 oceanfront properties from shoreline retreat (Cowell and Nelson, 1991). On the 172 eastern shore we focus on three drift-aligned beaches, Station Beach is on the

173 backshore of a sand barrier (shared with the open coast Palm Beach) (Fig. 1g). Further 174 south is Snapperman Beach, which lies north of a low-lying promontory and adjacent 175 to the flood-tide delta and a nearshore tidal channel; it has a partial seawall and is 176 backed by residential properties (Fig. 1g). Sand Point BEB occupies the south side of 177 the same promontory, has a partial seawall and is also backed by residential 178 properties (Short, 1993).

\subsubsection{Kamay}

180 The naturally and culturally significant Kamay (Botany Bay) is a marine-dominated 181 open embayment (Roy et al., 2001) $12 \mathrm{~km}$ south of Sydney (Fig. 1a-b). Kamay 182 occupies $\sim 39.6 \mathrm{~km}^{2}$ and has a maximum width and length of $5 \mathrm{~km}$ and $8 \mathrm{~km}$. The 183 average depth is $11.4 \mathrm{~m}$ and the bay has a SE-facing entrance that is $1.1 \mathrm{~km}$ wide 184 (OEH, 2018). Two rivers enter Kamay: The Cooks River in the NW of the estuary and 185 the Tucoerah (Aboriginal name for Georges River) in the SW (Fig. 1b). The estuary is 186 composed primarily of sandy sediments with some mud around the extensive 187 mangrove habitats on the southern shore (Jones, 1981). The estuary has been heavily 188 modified since the 1940s (Fig. 2), including river realignment, dredging and 189 reclamation to build and extend the port and airport (Fig. 1b), alongside ongoing 190 maintenance dredging and beach nourishment/stabilisation with groynes, rock 191 armament and revetments. 


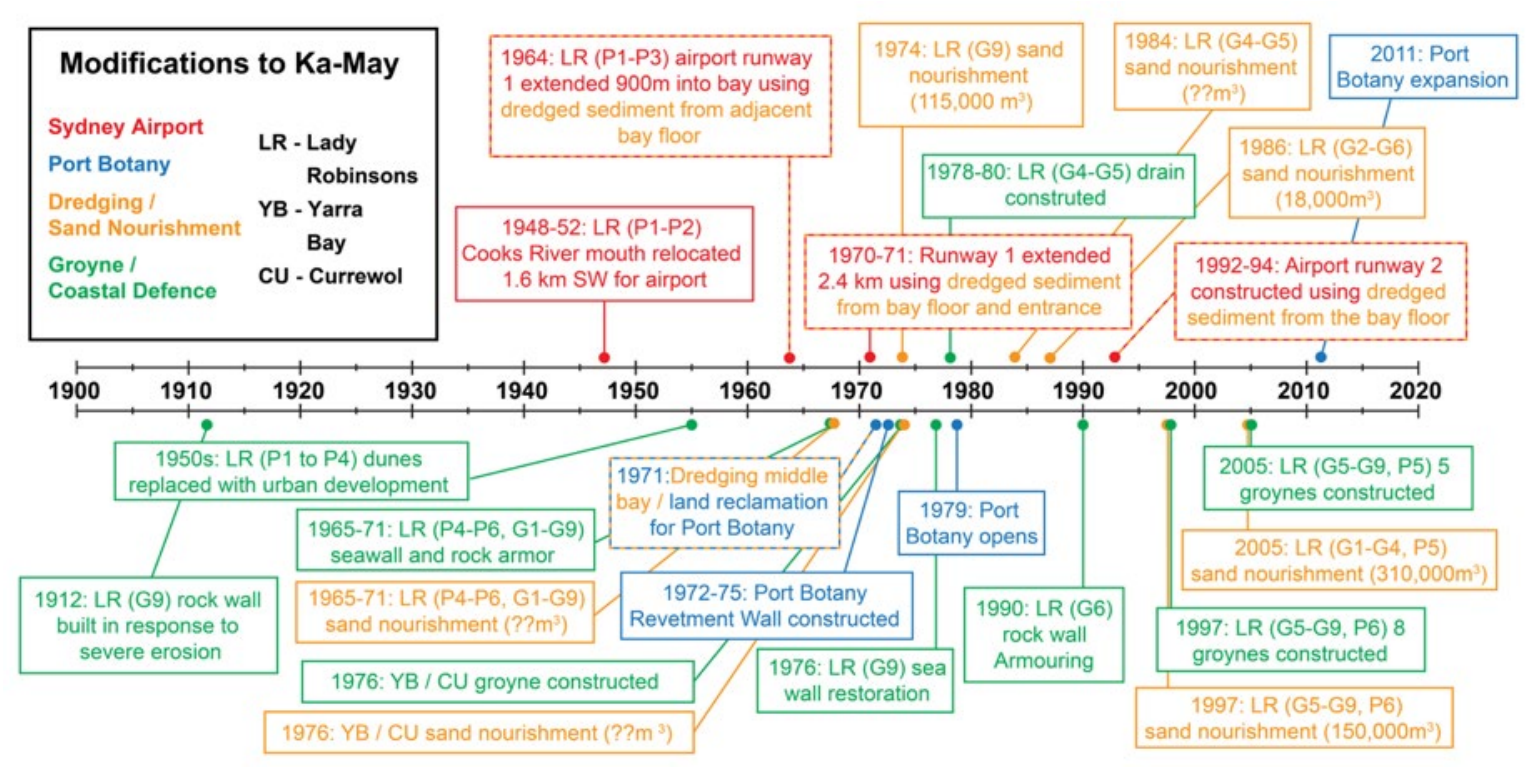

192 Figure 2: Timeline of anthropogenic intervention in Kamay from 1900. BEB and profile 193 locations are coloured by intervention type (red/blue/yellow/green or multiple). 194 Collated from Aijaz and Treloar (2003); Bryant and Kidd (1975); Cowell and Kannane 195 (2000); Davies and Mcllquham (2011); Frost (2011); Jones (1981).

We studied 5 BEBs in Kamay, including Congwong, Little Congwong, Currewol 197 (Aboriginal name for Frenchmans Bay) and Yarra Bay on the NE shore near the 198 entrance and Lady Robinsons on the western shore (Fig. 1d-e; Table 1). Congwong 199 and Little Congwong are swash-aligned pocket beaches inside a larger embayment. 200 They are both backed by well-developed dunes and being the closest to the entrance, 201 are exposed to S-SE swell waves (Short, 1993). Currewol and Yarra Bay, also swash 202 aligned, have low-lying vegetated dunes and Yarra is adjacent to the Port Botany 203 Revetment Wall (Fig. 1b, e). These 2 BEBs are west-facing and each have a central 204 groyne built in 1976 (Cowell and Kannane, 2000). Lady Robinsons, which is drift205 aligned, is bound by the Cooks and Tucoerah Rivers (Fig. 1d). This beach is at the 206 front of a prograding barrier that is heavily modified and adjacent to the airport in the 207 north. Groynes were constructed along the central and southern beach in 1997 and 2082005 (Cowell and Kannane, 2000) (Fig. 1d; Fig. 2). 


\section{METHODS}

$210 \quad$ 3.1. Image Georeferencing

211 We used a total of 100 images to form a shoreline timeseries at sub-decadal intervals

212 (Fig. 3; Supplementary Table S2). There were 33 vertical aerial images and 19 satellite 213 images between 1941 and 2017 for Pittwater, and 40 vertical aerial images and 8 214 satellite images between 1943 and 2017 for Kamay. Aerial images were geo-rectified 215 in Pittwater to a 2017 satellite image (NearMap Australia Pty Ltd), and to a 2014 216 Orthoimage for Kamay (Department of Planning, Industry and Environment, NSW 217 Government). We followed standard methodology ensuring the highest number of 218 fixed ground control points (GCPs) (Novak, 1992) using permanent fixed features such 219 as buildings, road intersections, jetties and geologic structures. We used 10-25 GCPs 220 per image (mean 11), depending on image resolution and identifiable features, to 221 perform a 2nd degree polynomial transformation (Rocchini et al., 2012). We calculated 222 root mean square error (RMSE), which corresponds to the sum of residual distances 223 between the location specified for a GCP and the place where it ends up after the 224 transformation (Rocchini et al., 2012). RMSE values were 0.5-5 m at Pittwater and $225 \quad 1.5-9.8 \mathrm{~m}$ at Kamay (mean $=3.5 \mathrm{~m})$.

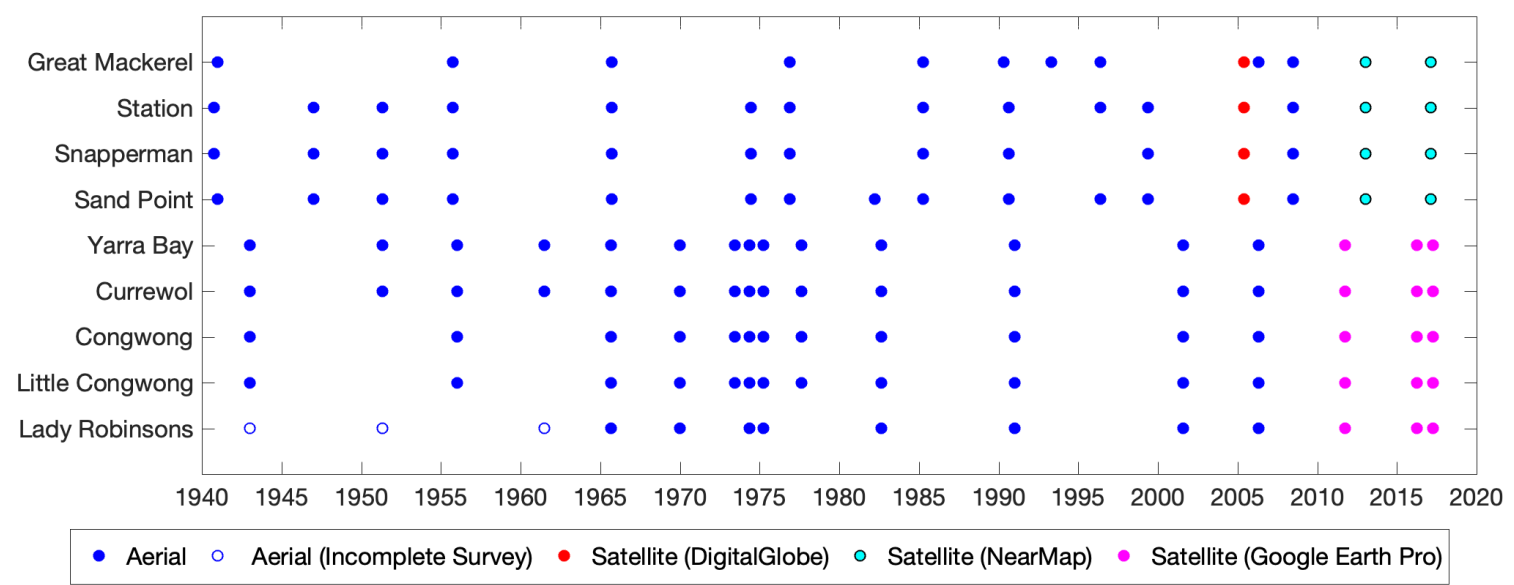

226 Figure 3: Timeseries of aerial and satellite imagery and sources used in this study to 227 track shorelines. 


\subsection{Decadal Shoreline Analysis}

229 We defined the shoreline as the high-water line (HWL) due to the clear contrast 230 between wet and dry sand in historical images, identified as a consistent shoreline 231 indicator by Boak and Turner (2005). In this region there is limited seasonal shoreline 232 variability for both open coast (Harley et al., 2016) and estuarine beaches (Kennedy, 233 2002), so infrequent (decadal) images are taken as representative of conditions that 234 year. Uncertainty in shoreline measurements include an error of $6 \mathrm{~m}$ associated with 235 tidal variability, estimated from a mean beach gradient of 10 degrees (Gallop et al., 2362020 ) and spring tidal range of $1.25 \mathrm{~m}$. This is combined with an error of $3 \mathrm{~m}$ for 237 onscreen delineation following Ruggiero et al. (2003), and the mean RMSE of $3.5 \mathrm{~m}$. 238 The total uncertainty of $7.5 \mathrm{~m}$ was calculated following Ruggiero et al. (2003) as the 239 root sum squared of the 3 individual error terms.

240 Beach width was measured from a profile with origins at the back-beach (seawall or 241 dune toe) to the shoreline identified in each image. The profiles are shore normal and 242 numbered alongshore from north to south (Fig. 1d-g; Table 1). Each of the 41 profiles 243 labelled with P (e.g., P1) in Figure 1 matches Gallop et al. (2020). We also measured

2449 groyne profiles with labelled with G (e.g., G1) located at the midpoint between groyne 245 pairs along the central and southern sections of Lady Robinsons in Kamay (Fig. 1d). 246 To determine decadal behaviour based on storm erosion and recovery we define the 247 BEB recovery timescale $t_{r}$, which is a function of the amount of sediment eroded 248 during a storm $E_{s}$ and the rate accretion between storms $A_{r}$, and compare this with 249 storm return timescales $t_{s t}$. 
251 We used offshore wave data for the Sydney region between 17/07/1987 and $25231 / 07 / 2017$ from a Waverider buoy located approximately $10 \mathrm{~km}$ offshore, at $90 \mathrm{~m}$ 253 water depth (Fig. 1a). The buoy is $22 \mathrm{~km}$ south of the Pittwater entrance and $30 \mathrm{~km}$ 254 north of the Kamay entrance. We used hourly measurements of $H_{s}$, maximum wave 255 height $\left(H_{\max }\right), T_{z}, T_{p}$ and $\theta$. Hourly measurements were processed to provide daily and 256 7-day moving averages and deep-water wave power $(P)$ was calculated following 257 Komar (1998) as:

$$
P=E C_{g}
$$

258 where wave energy $(E)$ is expressed as

$$
E=\frac{1}{16} p g H_{S}^{2}
$$

259 where $p$ is seawater density $\left(1025 \mathrm{~kg} / \mathrm{m}^{3}\right), g$ is gravitational acceleration $(9.81 \mathrm{~m} / \mathrm{s})$, 260 and wave group velocity $\left(C_{g}\right)$ is expressed as

$$
C_{g}=\frac{g T_{z}}{2 \pi} n
$$

261 where deep-water $n$ is 0.5 . Storms were identified using a Peaks-Over-Threshold 262 method described in Harley (2017) using $H_{s}=3 \mathrm{~m}$, for a minimum on 6 hours (Shand 263 et al., 2010). Finally, based on storm wave direction (available since 03/03/1992) and 264 entrance headland orientations we determined the overall estuary exposure to storms 265 as the number of storms that had wave directions that could propagate through each 266 entrance. 


\section{RESULTS}

\subsection{Storm wave exposure}

269 There were 481 storms during the study period; 427 of which occurred between 1992 and 2017 when wave direction measurements were available (Fig. 4). Mean storm

271 statistics were a duration of 33 hours, $H_{s}$ of $3.55 \mathrm{~m}, T_{z}$ of $7.6 \mathrm{~s}, T_{p}$ of a $10.8, \theta$ of $158^{\circ}$

272 and total storm power of $1350 \mathrm{Kw} / \mathrm{m}$ or $\sim 40 \mathrm{Kw} / \mathrm{m} /$ hour (Fig. 4). The Kamay entrance 273 faces SE ( 135 degrees) and is $1.1 \mathrm{~km}$ wide, so 380 storms ( $89 \%)$ had waves that 274 could propagate through giving a mean annual storm-exposure rate of 14.5 275 storms/year (Fig. 5). Conversely, the Pittwater Estuary entrance faces N-NE ( 25 276 degrees) and is $1 \mathrm{~km}$ wide, so only 37 storms (9\%) storms could propagate through, 277 giving a mean annual storm-exposure rate of 1.5 storms/year. Therefore, BEBs inside 278 Kamay are potentially exposed to 10 times more storms than in Pittwater (Fig. 5).

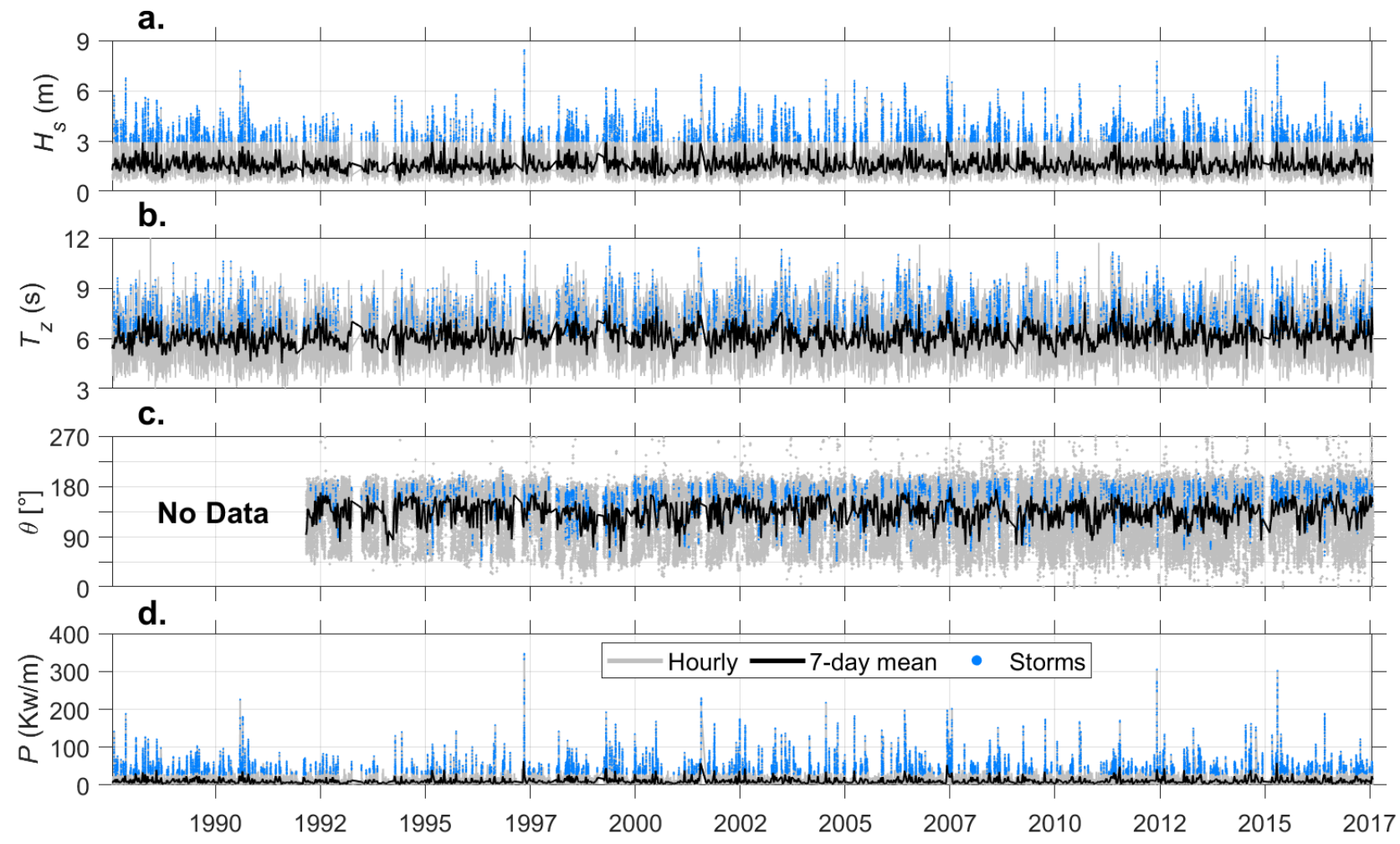

279 Figure 4: Sydney offshore wave data from 1987 to 2017, hourly (grey), 7-day mean 280 (black) and storms (light blue) measurements. (a) Significant wave height ( $\left.H_{s}\right)$, (b) 281 wave period $\left(T_{t}\right),(c)$ wave direction $(\theta)$ and $(d)$ wave power energy flux $(P)$. 


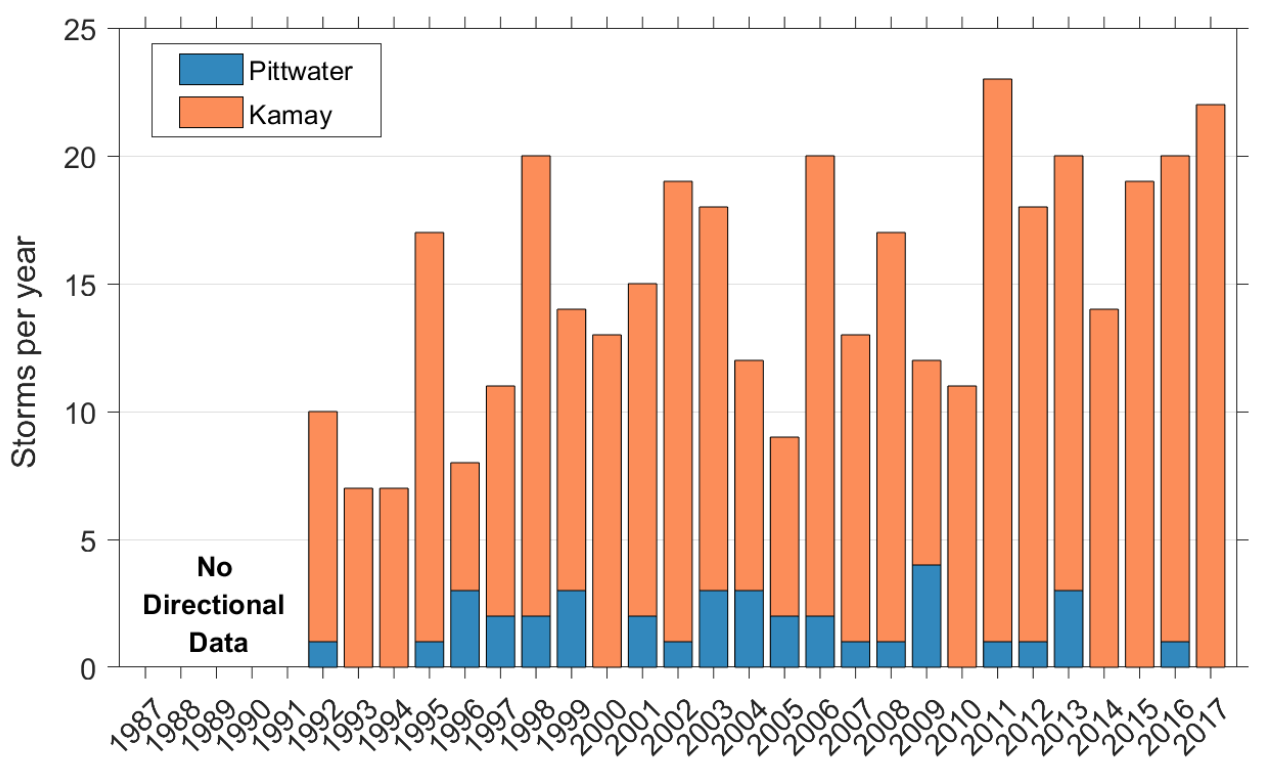

282 Figure 5: Number of storm events per year with storm wave directions that could pass 283 directly through the entrances of Pittwater (b/ue) and Kamay (orange).

\subsection{PITTWATER SHORELINE ANALYSIS}

\subsubsection{Western Shore: Great Mackerel}

286 Great Mackerel is the most swell-exposed BEB in Pittwater, being near the entrance and on the western shore in-line with the entrance (Fig. 1f). This beach exhibited the greatest decadal variability in beach width of the 4 Pittwater BEBs (Fig. 6a; Fig. 7a). Following the 1974 storm cluster, beach width was reduced up to $18 \mathrm{~m}$ (39\% pre-storm beach width) and the northern creek inlet (adjacent to P1) migrated $\sim 100$ m south towards P2 (Fig. 6a). These storms permanently narrowed the beach at P2 (by up to $40 \mathrm{~m}$ ), from a maximum in the mid-1950s. A storm in late 1988 again reduced width by up to $19 \mathrm{~m}$ (53\% beach width) and substantial localised flooding was recorded 294 (Supplementary Table S1). Following this, the beach continued to narrow, decreasing by $15 \mathrm{~m}$ in the 1990s, $10 \mathrm{~m}$ in the early 2000s (Fig. 6a; Fig. 7a) then a further $8 \mathrm{~m} \mathrm{r}(<$ $29667 \%$ beach width), aided by storms in 2007,2012 and 2016 . Some recovery occurred 297 between storms: almost complete recovery occurred 11 years after 1974 storms, only partial recovery 6 years following the 1988 storm, and partial recovery 5 years after 
2992011 storms (Fig. 7a). However, the general trend at Great Mackerel was a net loss 300 between 1941 and 2017 as the recovery timescale $\left(t_{r}\right)$ was longer than the storm 301 return timescale $\left(t_{s t}\right)$ - widths decreased between 5 and $33 \mathrm{~m}$ (mean $0.24 \mathrm{~m} /$ year), 302 faster at north (P2) and south (P5-P6) ends than mid-beach (P3) (Fig. 7a; Table 2).
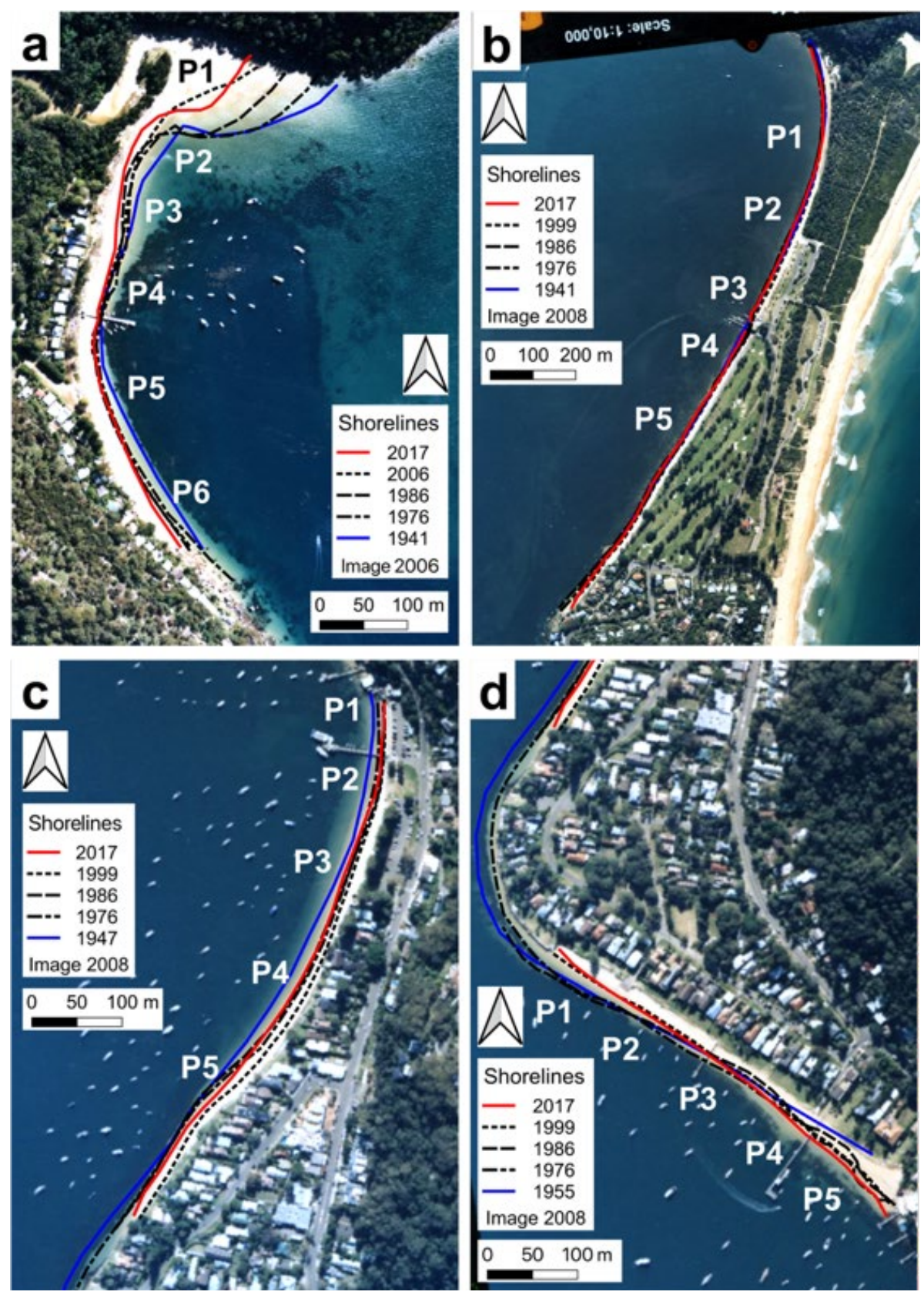

303 Figure 6: Pittwater estuary beaches (a) Great Mackerel, (b) Station, (c) Snapperman 304 and (d) Sand Point showing the first, last and $\sim 10$ yearly shorelines, with beach profiles 305 labelled. 
307 Station Beach is a backbarrier beach and the closest to the entrance on the eastern 308 shore (Fig. 1g; Fig. 6b; Fig. 7b). Shoreline erosion occurred in the early 1950s of up 309 to $8 \mathrm{~m}$ ( $40 \%$ of the pre-storm beach width), in 1974 up to $12 \mathrm{~m}$ ( $55 \%$ of the pre-storm 310 beach width), in 1998 up to $11 \mathrm{~m}$ (42\% of the pre-storm beach width), in 2007 up 311 to $6 \mathrm{~m}$ (32\% of the pre-storm beach width) and in 2016 up to $7 \mathrm{~m}$ (37\% of the pre312 storm beach width) (Fig. 6b; Fig. 7b). Notably, recovery took 5 years following the 313 1950s storms, 3 years following the 1974 storms, up to 10 years following the 1998 314 storm and the beach was partially recovered after the 2011 storms and before the 3152016 storm (Fig. 7b). However, the overall net change in beach width for P1-P4 was 316 negligible (within error) with the recovery timescale $\left(t_{r}\right)$ shorter or equal to storm return 317 timescale $\left(t_{s t}\right)$ - while the southern end (P5) increased width by $18 \mathrm{~m}(0.23 \mathrm{~m} / \mathrm{year})$ 318 (Fig. 7b; Table 2).

319 Snapperman beach widths did not change much (Fig. 1g; Fig. 6c; Fig. 7c). Between 320 storms in 1955 and 1974 the beach width reduced by up to 23 m (P3-P5) (Fig. 7c). 321 Following this, the central and south beach widths reduced by up to $11 \mathrm{~m}(22 \%$ of the 322 pre-storm beach width) in 1974 . The beach width reduced by up to $18 \mathrm{~m}(72 \%$ of the 323 pre-storm beach width) in 1998 storm, by up to $7 \mathrm{~m}$ in 2007 storm (100\% of the pre324 storm beach width) and by up to $7 \mathrm{~m}$ ( $88 \%$ of the pre-storm beach width) in 2016 storm 325 (Fig. 6c; Fig. 7c). Recovery took 5 years following the 1950 storms, 3 years following 326 the 1974 storms, was incomplete in 10 years following the 1988 storm, 11 years 327 following the 1998 storms and was partial 5 years after the 2011 storms (Fig. 7c). 328 However, the overall net change in beach width was negligible (P3-P5) and therefore 329 the recovery timescale $\left(t_{r}\right)$ was shorter or equal to storm return timescale $\left(t_{s t}\right)$ - except 
330 at the northern end (P1-P2) where width was reduced up to $17 \mathrm{~m}(0.22 \mathrm{~m} /$ year) (Fig.

331 7c; Table 2).

332 Table 2: Net BEB width change (rate of change) $m$ (m/year) between 1941 333 (Pittwater)/1943 (Kamay) and 2017 and before $\left(^{*}\right)$ and after groyne construction $\left({ }^{* *}\right)$. 334 Positive indicates beach widening and negative indicates beach narrowing and bold 335 values are changes above the method uncertainty $(7.5 \mathrm{~m})$. ' $\dagger$ ' denotes change from 3361965 (first image) at Lady Robinsons G8-9.

\begin{tabular}{|c|c|c|c|c|c|c|c|}
\hline & BEB & P1 & P2 & P3 & P4 & P5 & P6 \\
\hline \multirow{4}{*}{ 离 } & $\begin{array}{l}\text { Great } \\
\text { Mackerel }\end{array}$ & - & $-33.0(-0.43)$ & $-19.0(-0.25)$ & $-5.0(-0.07)$ & $-11.0(-0.14)$ & $-24.0(-0.32)$ \\
\hline & Station & $-3.0(-0.04)$ & $-3.0(-0.04)$ & $-2.0(-0.03)$ & $-8.0(-0.11)$ & $17.6(0.23)$ & - \\
\hline & Snapperman & $-11.0(-0.14)$ & $-17.0(-0.22)$ & $-6.0(-0.08)$ & $-4.0(-0.05)$ & $-4.0(-0.05)$ & - \\
\hline & Sand Point & $4.0(0.05)$ & $7.0(0.09)$ & $12.0(0.16)$ & $22.0(0.29)$ & $29.0(0.38)$ & - \\
\hline \multirow{8}{*}{ 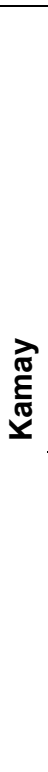 } & Yarra Bay & $\begin{array}{c}-4.8(-0.06) \\
-29.0(-0.88)^{\star} \\
17.1(0.42)^{\star *} \\
-11.5(-0.16) \\
-15.8(-0.48)^{\star} \\
-1.6(0.04)^{\star *}\end{array}$ & $\begin{array}{c}30.3(0.41) \\
16.4(0.50)^{\star} \\
3.6(0.09)^{\star *} \\
0.8(0.01) \\
-30.9(-0.93)^{\star} \\
2.8(0.07)^{\star *}\end{array}$ & $\begin{array}{c}61.1(0.83) \\
59.5(1.80)^{*} \\
1.0(0.02)^{\star *} \\
-2.1(-0.03) \\
-9.1(-0.28)^{*} \\
5.0(0.12)^{* *}\end{array}$ & $\begin{array}{c}51.3(0.69) \\
8.1(0.25)^{\star} \\
41.6(1.01)^{\star *} \\
-13(-0.18) \\
-8.9^{*}(-0.27) \\
-5.6^{* *}(-0.14)\end{array}$ & $\begin{array}{c}- \\
-7.8(-0.11) \\
3.1(0.09)^{\star} \\
-5.3(-0.13)^{\star \star}\end{array}$ & - \\
\hline & Congwong & $10.6(0.14)$ & $10.8(0.15)$ & $10.3(0.14)$ & - & - & - \\
\hline & $\begin{array}{l}\text { Little } \\
\text { Congwong }\end{array}$ & $2.3(0.03)$ & $1.9(0.03)$ & $3.2(0.04)$ & - & - & - \\
\hline & $\begin{array}{l}\text { Lady } \\
\text { Robinsons } \\
\text { (Profiles) }\end{array}$ & $59.8(0.81)$ & $15.9(0.22)$ & $3.80(0.05)$ & $24.5(0.33)$ & $\begin{array}{c}10.4(0.14) \\
-29.8(-0.48)^{*} \\
-6.0(-0.50)^{\star *}\end{array}$ & $\begin{array}{l}10.0(0.14) \\
2.7(0.05)^{\star} \\
3.0(0.15)^{\star *}\end{array}$ \\
\hline & \multirow{4}{*}{$\begin{array}{l}\text { Lady } \\
\text { Robinsons } \\
\text { (Groynes) }\end{array}$} & G1 & G2 & G3 & G4 & G5 & G6 \\
\hline & & $\begin{array}{c}12.9(0.17) \\
-9.0(-0.14)^{\star} \\
2.5(0.21)^{\star *}\end{array}$ & $\begin{array}{c}5.8(0.08) \\
-25.4(-0.41)^{*} \\
-11.9(-0.99)^{\star *}\end{array}$ & $\begin{array}{c}-13.2(-0.18) \\
-10.2(-0.16)^{\star} \\
-30.1(-2.51)^{\star *}\end{array}$ & $\begin{array}{c}5.0(0.07) \\
-2.9(0.05)^{\star} \\
-\mathbf{2 1 . 4}(-1.79)^{\star *}\end{array}$ & $\begin{array}{c}-8.9(-0.12) \\
-2.3(-0.04)^{\star} \\
-13.9(-0.69)^{\star *}\end{array}$ & $\begin{array}{l}-11.1(-0.15) \\
-14.7(-0.27)^{\star} \\
-18.2(-0.91)^{\star *}\end{array}$ \\
\hline & & G7 & G8 & G8 & - & - & - \\
\hline & & $\begin{array}{c}-21.0(-0.28) \\
24.2^{*}(-0.45)^{\star} \\
-5.4^{*}(-0.27)^{\star *}\end{array}$ & $\begin{array}{l}-24.9(-0.48) \dagger \\
-15.4(-0.48) \dagger^{*} \\
-40.8(-2.04)^{\star *}\end{array}$ & $\begin{array}{l}31.7(0.61) \dagger \\
8.2(0.26) \dagger^{*} \\
2.6(0.13)^{\star *}\end{array}$ & - & - & - \\
\hline
\end{tabular}

337 Sand Point is the furthest $(\sim 2.7 \mathrm{~km})$ from the Pittwater entrance (Fig. 1g). Despite this, 338 there was a significant shoreline response to storms (Fig. 6d; Fig. 7d). This beach was 339 impacted by the 1950 storm cluster when the beach rotated clockwise, reducing width 340 by $6 \mathrm{~m}$ (18\% of the pre-storm beach width) in the north (P1) and increasing width by $3418 \mathrm{~m}$ (20\% beach width) in the south (P5) (Fig. 7d). The 1974 storms reduced widths 342 along the entire beach, by up to $12 \mathrm{~m}$ ( $29 \%$ of the pre-storm beach width). The beach 343 width was then stable from the late-1970s until the 1998 storms when beach widths 344 were reduced by up to $8 \mathrm{~m}$ (16\% of pre-storm beach width) and again in 2011 by up 


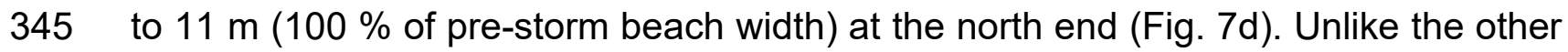

346 Pittwater beaches, beach width was not noticeably impacted by the storms in 1988,

3472007 or 2016. Beach recovery took up to 5 years following the 1950 storms, 3 years

348 following the 1974 storms and recovered following the 2011 storms before the 2016

349 storm (Fig. 7d). Overall, Sand Point was stable with a recovery timescale $\left(t_{r}\right)$ shorter

350 or equal to storm return timescale $\left(t_{s t}\right)$, however the shoreline rotated clockwise: at

351 northern end (P1-P2) it narrowed by up to $7 \mathrm{~m}(0.09 \mathrm{~m} / \mathrm{year})$ while at central and

352 southern sites (P3-P5) it prograded by $29 \mathrm{~m}$ (0.38 m/year) (Fig. 7d; Table 2).

a. Great Mackerel

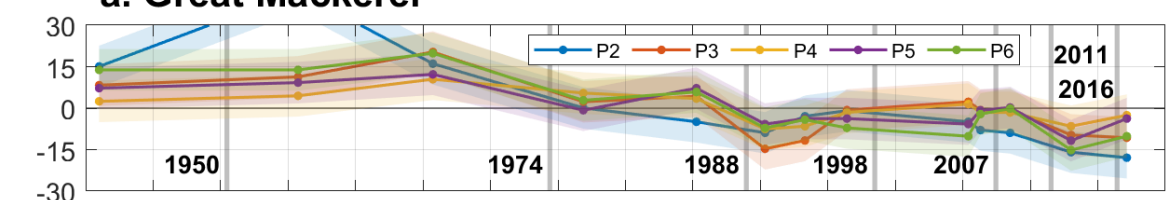

b. Station
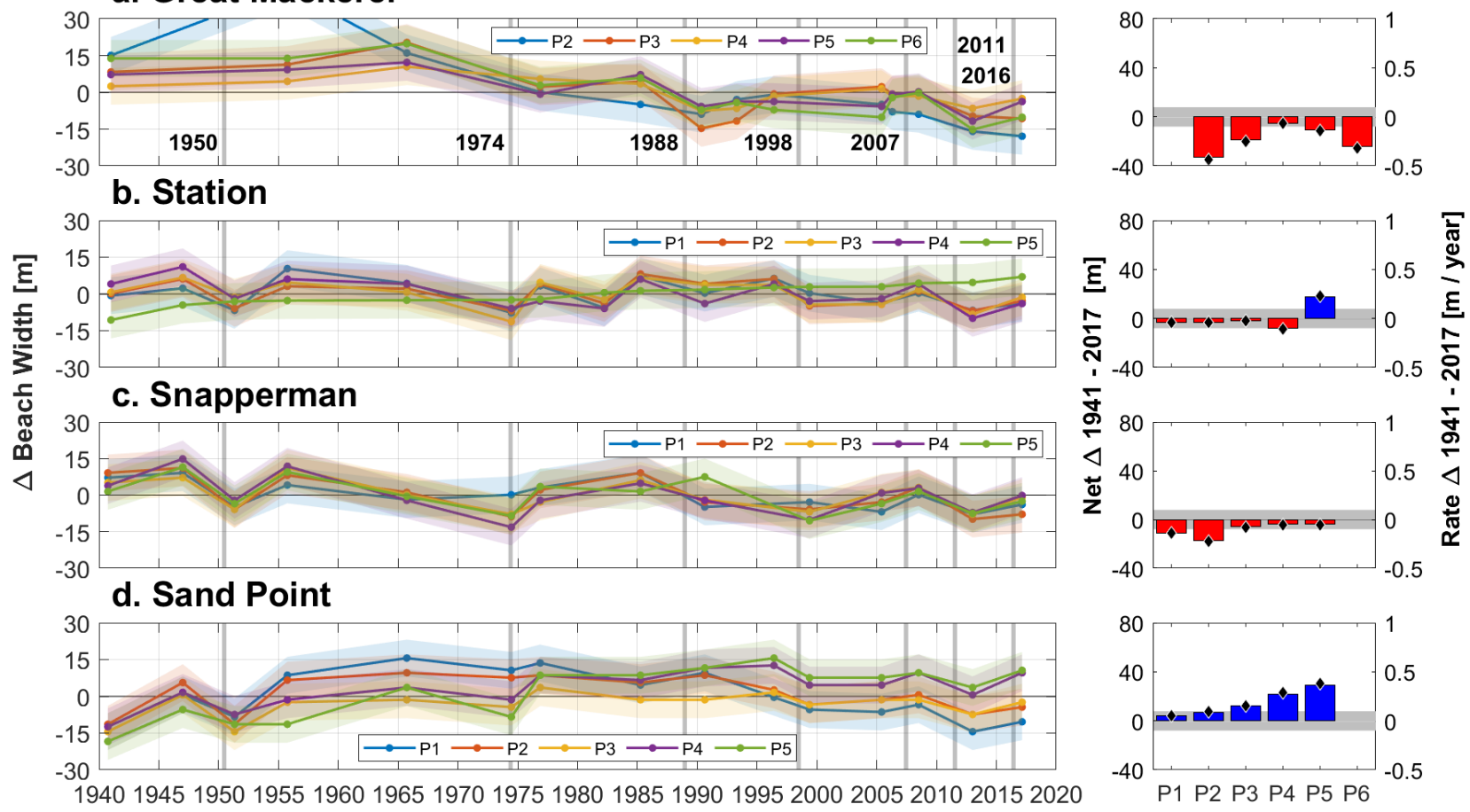

353 Figure 7: (left) Timeseries of beach width (difference from mean) at (a) Great

354 Mackerel, (b) Station, (c) Snapperman and (d) Sand Point (right) Net change in beach 355 width $(m)$ between 1941 and 2017 is shown as net increase (blue) and decrease (red), 356 and annual rates of change (m/year) (black diamonds). The shaded areas in all plots 357 represent the total uncertainty $(7.5 \mathrm{~m})$ and notable storms are shown by the vertical 358 grey lines (Supplementary Table S1). 
4.3.1. Northeast Shore: Yarra Bay, Currewol, Congwong and Little Congwong

362 Yarra Bay on the northeast shore of Kamay, adjacent to the Port Botany Revetment 363 Wall, exhibited notable decadal variability (Fig. 1e; Fig. 8a; Fig. 9a). In the 1940s the 364 southern half of the Yarra embayment (P3-P4) had limited or no sediment with 365 underlying rocks exposed; in comparison, the northern beach (P1-P2) had ample sediment (Fig. 8a). By the 1960s the beach had started to accrete at the southern end, 367 although some rocks were still exposed between P3 and P4. By the mid-1970s, 368 following dredging for the port and the 1974 storms, the beach underwent extreme erosion at the northern end (P2), with widths reduced by up to $23 \mathrm{~m}(90 \%$ of the pre370 storm beach width) and erosion encroached into the dunes (Fig. 2; Fig. 9a). These 371 impacts led to clockwise shoreline rotation, with the northern end narrowing and the 372 southern end widening (Fig. 9a). Following the damaging 1974 storms the beach 373 recovered partially in the 2 years (P1) prior to the groyne construction and sand 374 nourishment in 1976 (Fig. 2; Fig. 9a). Other notable storm erosion and recovery 375 responses were masked by anthropogenic interventions and a recovery timescale $\left(t_{r}\right)$ 376 that was shorter or equal to storm return timescale $\left(t_{s t}\right)$ (Fig. 8a). The overall trend 377 (1943-2017) was accretional with widths increasing by up to $60 \mathrm{~m}$ (0.83 m/year) 378 closest to the groyne (Fig. 8a; Table 2). 


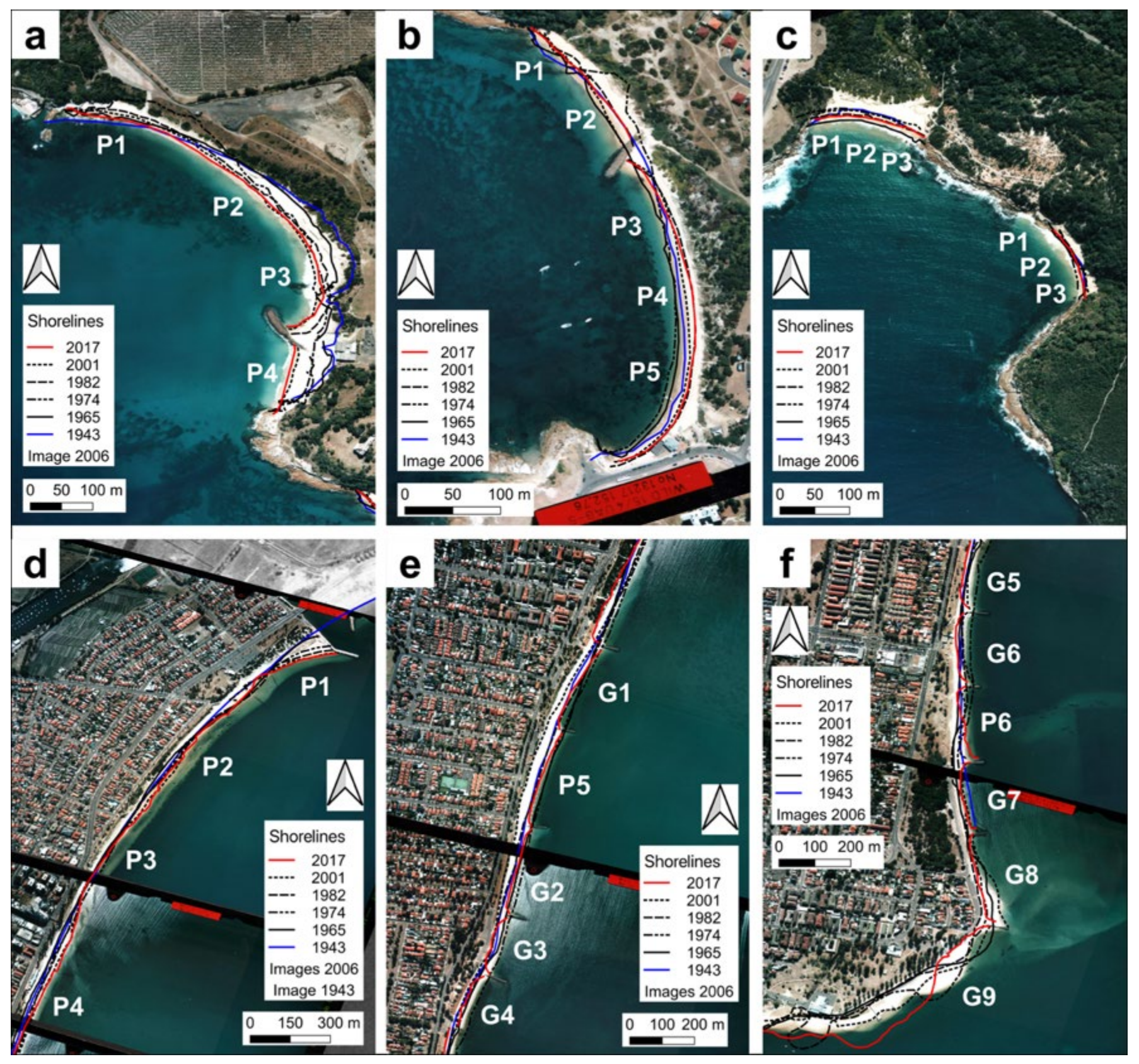

379 Figure 8: Decadal shorelines in Kamay with the first, last and $\sim 10$ yearly shorelines 380 are shown, and profiles are labelled. (a) Yarra Bay, (b) Currewol, (c) Congwong (left) 381 and Little Congwong (right), Lady Robinsons North (d), Central (e) and South (f). The 382 red squares are watermarks.

383 At Currewol, the northern end (P1-P3) is more exposed to waves propagating through

384 the entrance and exhibited larger changes in beach width than the more-sheltered 385 southern end (P4-P5) (Fig. 1e; Fig. 8b; Fig. 9b). Following storms in the early 1950s 386 beach widths were reduced by up to $12 \mathrm{~m}$ (61\% of the pre-storm beach width), and 
again by up to $6 \mathrm{~m}$ ( $31 \%$ of the pre-storm beach width) after the 1974 storms. Following 388 the 1974 storms, the shoreline rotated clockwise from P1 to P5 with the northern profiles narrowing by up to $20 \mathrm{~m}$ ( $211 \%$ of the pre-storm width) and caused expansive erosion to the dunes (Fig. 9b). There was limited or no recovery in the following 2 391 years (Fig. 8b). This prompted the construction of a groyne and nourishment in 1976, 392 similar to Yarra Bay (Fig. 2). The beach was stable after these interventions, until the 393 2007 and 2011 storm clusters combined reduced widths up to 9 m (38 \% of pre-2007 storms beach width). Recovery to pre-2007 widths took up to 9 years (Fig. 9b). Overall 395 changes in beach width (1943-2017) saw the northern (P1) and central-south beach (P4) reduced up to $13 \mathrm{~m}(-0.18 \mathrm{~m} / \mathrm{year})$, while the centre beach (P3) was negligible (Fig. 9b; Table 2) suggesting recovery timescale $\left(t_{r}\right)$ is shorter or equal to storm return 398 timescale $\left(t_{s t}\right)$.

Congwong and Little Congwong are the most exposed BEBs in Kamay and shorelines at both beaches showed little change, fluctuating by $\pm 10 \mathrm{~m}$ with recovery timescale $401\left(t_{r}\right)$ shorter or equal to storm return timescale $\left(t_{s t}\right)$ (Fig. 1e; Fig. 8c; Fig. 9c-d). These 402 BEBs were impacted by the 1974 storm cluster when Congwong eroded by up to $6 \mathrm{~m}$ 403 (31\% of the pre-storm beach width) and Little Congwong accreted by up to $12 \mathrm{~m}$ ( $76 \%$ 404 pre-storm beach width); the shoreline also rotated clockwise from north to south at 405 Little Congwong (Fig. 9c-d). The 1950, 1998, 20072012 and 2016 storms caused 406 negligible responses. Following the 1974 storms, Congwong recovered $50 \%$ of widths 407 within a year and both BEBs had recovered fully in 3 years (Fig. 9c-d). The overall 408 trend (1943-2017) at Congwong had widths increased up to $10 \mathrm{~m}(0.14 \mathrm{~m} / \mathrm{year})$, while 409 at Little Congwong net change was negligible (Fig. 9c-d; Table 2). 


\section{a. Yarra Bay}

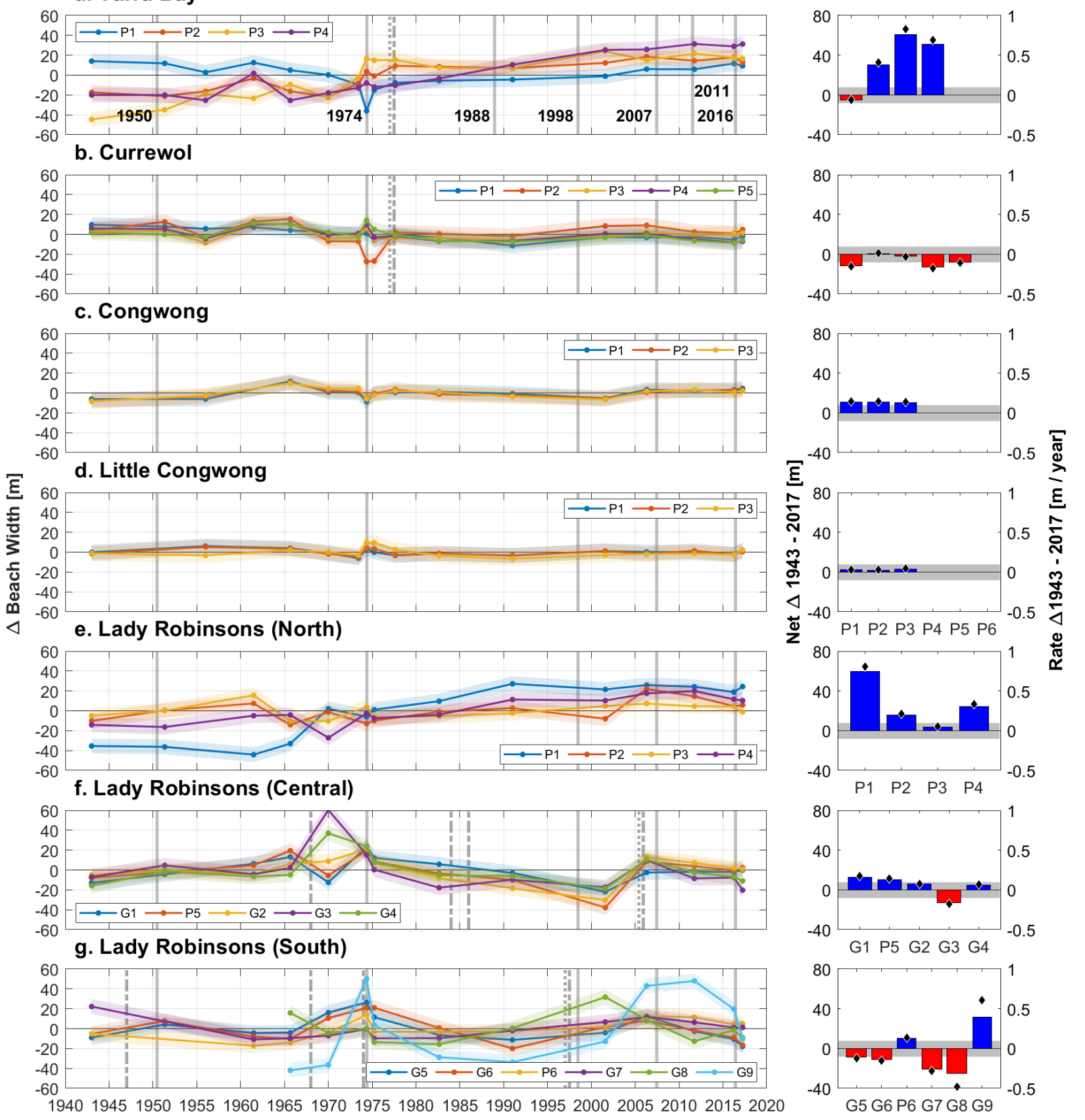

410 Figure 9: (left) Timeseries of beach width (difference from mean) for (a) Yarra Bay,

411 (b) Currewol, (c) Congwong, (d) Little Congwong and Lady Robinsons north (e), 412 central (f) and south (g). (right) Net change in beach width (m) between 1943 and 2017 413 with net increase (b/ue) and decreases (red), and rates of change (m/year) (black 414 diamonds). Note the shaded areas in both the left and right plots represent the total 415 uncertainty $(7.5 \mathrm{~m})$, notable storms (solid grey lines) (Supplementary Table S1), 416 groyne construction (grey dotted lines), sand nourishment (grey dot-dash lines) and 417 the net rates for G8 and G9 in (g) were calculated between 1965 (first image) and 4182017. 
420 Lady Robinsons is the farthest from the estuary entrance $(8.2 \mathrm{~km})$ and has the most

421 anthropogenic interventions (Fig. 1d; Fig. 9e-g). There were significant differences in 422 shoreline behaviour between the northern, central and southern sections. The 423 northern section (P1-P4) accreted overall (1943-2017) with beach widths increasing

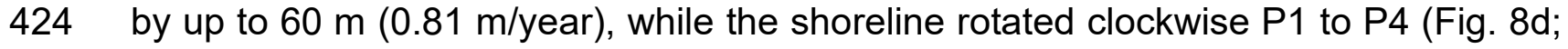
425 Fig. 9e; Table 2). The 1974 storm cluster impacted the beach (P3) narrowing it by $42610 \mathrm{~m}$ (44\% of the pre-storm width) (Fig. 9e). The profiles affected by these storms 427 were accreted before the storms and did not recover to pre-1974 widths until 1990. 428 Subsequent storms did not impact this section due to the airport runway extensions 429 (Fig. 2; Fig. 9e).

430 The beach widths on the central section of Lady Robinsons (P5, G1-G4) continually 431 narrowed requiring intervention (Fig. 1d; Fig. 9f). This section was eroded following 432 the 1974 storms by $11 \mathrm{~m}$ (19\% pre-storm beach width) and then continued to lose 433 sand coinciding with dredging for the runways in the 1990s (Fig. 2); these losses were 434 reversed when groynes were constructed in 2005 (Fig. 8e; Fig. 9f). The 2007 and 2011 435 storm clusters and the 2016 storm further eroded this section with limited recovery 436 recorded by the end of this study, suggesting recovery timescales $\left(t_{r}\right)$ are longer than 437 the storm return timescale $\left(t_{s t}\right)$ (Fig. 9f). Although the storms and dredging reduced 438 beach widths, repeated sand nourishment increased the net beach width (1943-2017) 439 up to $12.9 \mathrm{~m} /$ year $(0.17 \mathrm{~m} /$ year $)$, although this is not the case at G3 which had overall 440 width reduced by 13.2 m/year (0.18 m/year) (Fig. 2; Fig. 9f; Table 2).

441 Beach widths in the southern section (P6, G5-G9) were characterised by large 442 shoreline fluctuations and decadal shoreline retreat that were mitigated by four sand 
443 nourishment interventions in 1943, 1964, 1971 and 1997 (Fig. 1d; Fig. 2; Fig. 9g). The

4441974 storms reduced beach width by up to $17 \mathrm{~m}$ ( $80 \%$ of the pre-storm beach width)

445 with only one profile recovering 15 years later (G8) (Fig. 9g). Groynes were built in 4461997 to stabilise this section, however the 2007, 2011 and 2016 storms again eroded

447 this section with no recovery between storms, suggesting recovery timescales $\left(t_{r}\right)$ in

448 this section were longer than the storm return timescale $\left(t_{s t}\right)$ (Fig. $\left.9 \mathrm{~g}\right)$. Shorelines

449 between the groynes had anti-clockwise orientations (Fig. 8f), indicating southward 450 longshore transport. Overall change in beach width (1943-2017) was varied, with the 451 southernmost site (G9) accreted $30 \mathrm{~m}$ (0.61 m/year) while the adjacent beach (G8) 452 eroded by 24.9 m (-0.48 m/year) (Fig. 8f; Table 2).

\section{DISCUSSION}

\subsection{Decadal behaviours of BEB shorelines}

455 Considerable erosion of BEBs occurred during storms when ocean swell waves 456 propagated through the entrances of semi-enclosed estuaries. During low-energy 457 wave conditions between storms, transport of sand back onto beaches was slow and 458 post-storm recovery took years. In previous work (Costas et al., 2005; Gallop et al., 459 2020; Harris et al., 2020; Nordstrom and Jackson, 2012), incomplete recovery was 460 observed over months to several years, while here we show that some BEBs can 461 recover fully after storms, given enough time (Fig. 9c, $f$ and 10). The level of BEB 462 recovery depends on the recovery time relative to the return time of storms. When 463 storms occur frequently or at beaches where recovery time is slow, the recovery 464 timescale $\left(t_{r}\right)$ may be longer than the storm return timescale $\left(t_{s t}\right)$ and recovery will be 465 incomplete. Our results include BEB shorelines where $t_{r}>t_{s t}$ and others where $466 t_{r}<t_{s t}$ or $t_{r} \sim t_{s t}$, representing different decadal-scale behaviours (Fig. 7; Fig. 9; Fig. 467 10). Based on the BEBs in this study (Fig. 10; Table 3), we propose a decadal 
468 behavioural typology of BEB shorelines: prograding, quasi-stable, retreating and relict

469 BEBs. Where $t_{r}<t_{s t}$, beaches recover between storms as they do on the open coast;

470 these quasi-stable BEBs show limited decadal-scale change. They may occur where

471 beaches are entirely sheltered from storm waves (Currewol post-1974) or exposed to

472 significant wave energy between storms and available sediment sources (e.g.,

473 Congwong and Little Congwong, Fig. 9b-c). This supports Costas et al. (2005) who

474 suggest that wave exposure is vital for any beach recovery. However, where $t_{r}>t_{s t}$,

475 beaches cannot recover before the next erosion event; these retreating BEBs exhibit

476 partial recovery between storm events (e.g., Great Mackerel). Some beaches

477 exhibited negligible recovery between storms (Table 3) - these relict BEBs (e.g., Lady

478 Robinsons south) appear unrelated to modal conditions (relict) and reflect prior storm

479 erosion. These BEBs may have formed under different environmental conditions and,

480 without further intervention, could eventually disappear under contemporary

481 conditions. Finally, we also observed prograding BEBs (e.g., Sandy Point, Lady

482 Robinsons north). Although the mechanisms and sediment sources for this behaviour

483 are unknown (Gallop et al., 2020), reduced swell exposure (far removed from ocean

484 entrance) and alongshore transport are likely factors in this progradation (Fig. 7d;

485 Fig. 9d). As for relict BEBs, these prograding BEBs may also reflect environmental 486 change (i.e., local sediment budget has been altered). 


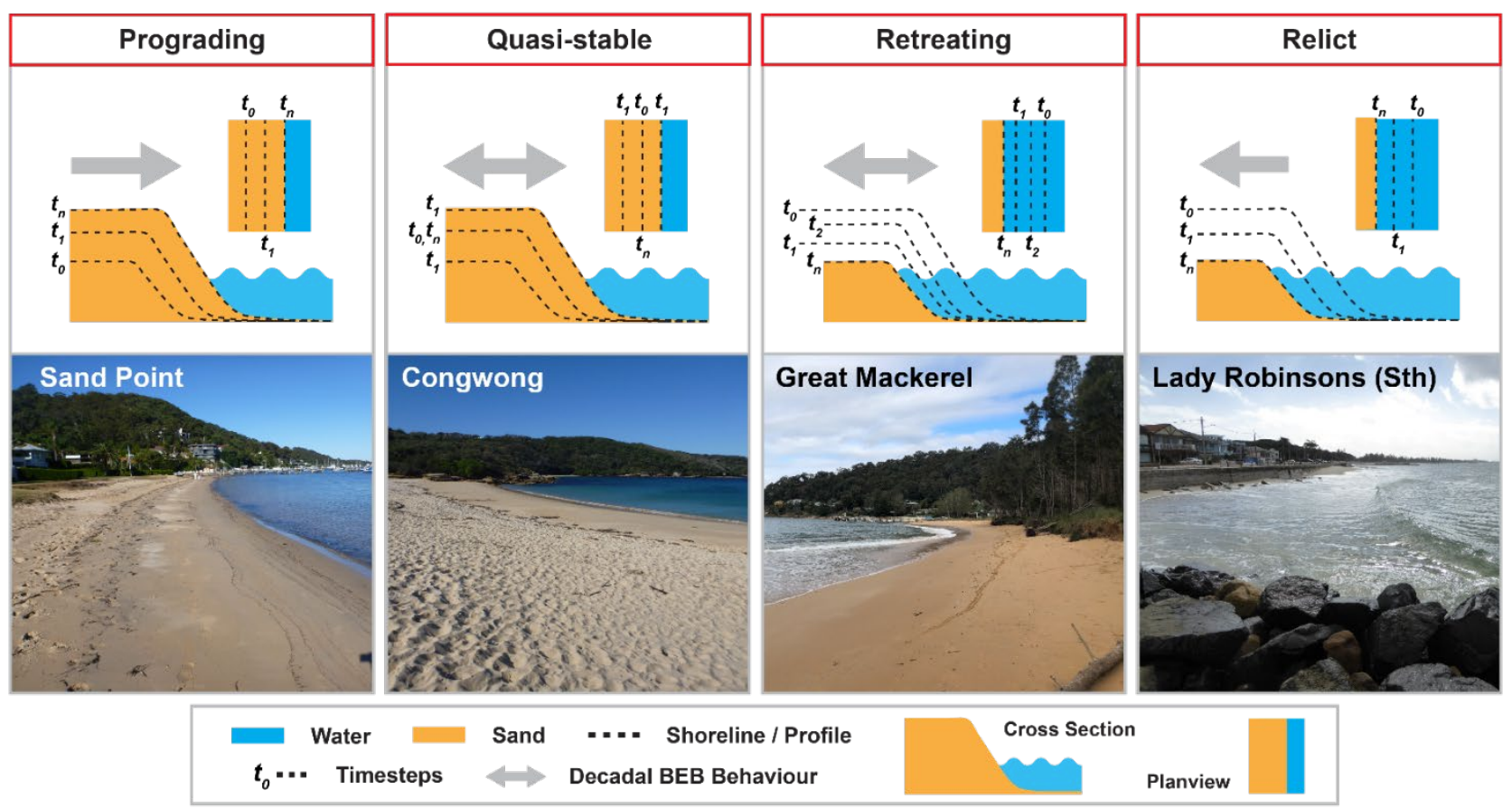

487 Figure 10: A decadal behavioural typology for BEBs. Prograding, Quasi-stable, 488 retreating, and Relict. Behaviours are shown with an example BEB from Pittwater and 489 Kamay.

490 A key finding is that BEB shoreline recovery is slower than open-coast beaches, which 491 is typically within 3 years following extreme storms in this region (Harley et al., 2016).

492 If we note that recovery time $t_{r}=E_{s} / A_{r}$ where $E_{s}$ is amount eroded during storm and $493 A_{r}$ is the rate of accretion between storms, then the requirement for quasi-stable 494 beaches is $t_{s t}>E_{s} / A_{r}$. Thus beaches may start to retreat due to increased storm 495 frequency (smaller $t_{s t}$ ), more severe erosion during storms (larger $E_{s}$ ), or slower 496 accretion between storms (smaller $A_{r}$ ). In some areas, climate change may alter storm 497 frequency, wave height and incident direction, which change $E_{s}$. Moreover, local 498 anthropogenic changes like dredging and structures can alter wave propagation into 499 estuaries/bays, changing both $E_{s}$ and $A_{r}$; structures can alter $E_{s}$ and $A_{r}$ while 500 nourishment can increase $A_{r}$. More recognition of the influence of anthropogenic 501 impacts alongside the slow-evolution paradigm for BEBs has major implications for 502 the management of estuary and bay shorelines in major cities. 
Table 3: Decadal behavioural typology of the BEBs in Pittwater and Kamay.

\begin{tabular}{|c|c|c|c|}
\hline & BEB Location & Behaviour & Behaviour after intervention \\
\hline \multirow{8}{*}{ 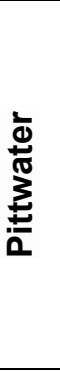 } & & Retreating (north/south) & Retreating (north/south) \\
\hline & Great IVlackerel & Quasi-stable (central) & Quasi-stable (central) \\
\hline & Station & Quasi-stable (north) & \\
\hline & Station & Prograding (south) & - \\
\hline & Snannerman & Retreating (north) & \\
\hline & snapperman & Quasi-stable (central/south) & - \\
\hline & & Quasi-stable (north) & \\
\hline & Sand Point & Prograding (south) & - \\
\hline \multirow{9}{*}{ 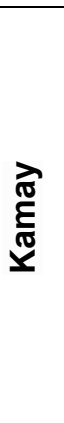 } & & Relict (north) & \\
\hline & Yarra Bay & Quasi-stable (south) & Quasl-stable (all) \\
\hline & Currewol & Relict (north) & Quasi-stable (all) \\
\hline & & Quasi-stable (south) & \\
\hline & Congwong & Quasi-stable & - \\
\hline & Little Congwong & Quasi-stable & - \\
\hline & & Quasi-stable (north) & Prograding (north) \\
\hline & Lady Robinsons & Relict (central) & Quasi-stable (central) \\
\hline & & Relict (south) & Retreating (south) \\
\hline
\end{tabular}

\subsection{Geomorphological influences on decadal BEB evolution}

\subsubsection{Distance from estuary or bay entrance}

506 Distance from the estuary/bay entrance controls BEB responses to and recovery from 507 storms (Fig. 7b; Fig. 9c). BEBs that are close to the entrance present behaviours that 508 are commonly quasi-stable (e.g., Congwong and Station); in contrast with prograding, 509 retreating and relict behaviours away from the entrance (Fig. 10; Table 3). Costas et 510 al. (2005), Eulie et al. (2017) and Gallop et al. (2020) suggest that exposure to swells 511 and a continuing supply of marine sediment are essential to maintain BEB shorelines 512 (Fig. 7b; Fig. 9c). For instance, Kamay has $\sim 10$ times the number of storms that with 513 waves that enter the estuary compared to Pittwater (Fig. 5). In Kamay, following the 5141974 storms, BEBs located near an entrance exhibited rapid recovery, e.g., 515 Congwong close to the entrance recovered in 3 years and was quasi-stable compared 516 to Lady Robinsons south which is $6 \mathrm{x}$ further from the entrance and had only partial 517 recovery after 15 years and was retreating/relict. (Fig. 9c, g; Table 3). Alternatively, 518 BEBs that have prograding behaviours (e.g., Sand Point) may be at the inner limit of 
519 swell propagation where waves no longer have energy required to transport marine

520 sediments (Fig. 6d; Fig. 8d; Fig. 10); suggesting that prograding BEBs are controlled

521 by tidal, wind-wave or other processes. For example, Austin et al. (2018) and Vila-

522 Concejo et al. (2020) found that wave energy within estuaries can be

$523 \mathrm{refracted} / \mathrm{diffracted}$ around headlands, along estuary/bay shores and over tidal shoals

524 and deltas, encouraging alongshore transport on BEBs. Overall, we suggest that

525 entrance-adjacent BEBs may be less vulnerable to decadal management issues and

526 more attention may be required for those with less stable behaviours.

\subsubsection{Flood-tide deltas}

528 A flood-tide delta may act as a source or sink for BEB sediments (Austin et al., 2018;

529 Vila-Concejo et al., 2011). For example, Great Mackerel had a sediment sink 530 (retreating) while Snapperman had a sediment source (quasi-stable) (Fig. 7a, c). Both 531 of these BEBs are adjacent to the Pittwater flood-tide delta but have different 532 behaviours (Table 3) and exposure to swells (Gallop et al., 2020). Harris et al. (2020) 533 and Vila-Concejo et al. (2007) indicate that BEB sediments can be transported by 534 storm waves onto flood-tide deltas and sandy tidal shoals, with this transport becoming 535 permanent if sediments are moved below the modal wave base (Austin et al., 2018) 536 or removed by subsequent tidal action. Gallop et al. (2020) outline the retreating 537 behaviour at Great Mackerel (Table 3), suggesting that sediments eroded from the 538 shoreface post-storm may be transported alongshore or form a subtidal terrace that 539 extends to flood-tide deltas and may be a one-way process where sediment is 540 transported over the delta-front into deeper water. These authors and others (Costas 541 et al., 2005; Jackson, 1995; Nordstrom and Jackson, 2012) state that the limited wave 542 energy under modal conditions can fail to return all eroded BEB sediments. 543 Alternatively, sediments may arrive onto BEBs from nearshore sources (Vila-Concejo 
544 et al., 2010; Vila-Concejo et al., 2007) or have travelled along estuary/bay shores from

545 the entrance (Harris et al., 2020). This is evident whereby sediments transported along

546 the eastern estuarine shore between Station and Snapperman (both quasi-stable),

547 with the latter adjacent to the flood-tide delta (Fig. 1g; Table 3). Meanwhile, similar

548 shoreline decadal shoreline erosion is evident at other sites near flood-tide delta in

549 Port Stephens in SE Australia (Austin et al., 2018; Harris et al., 2020) as well as 550 adjacent to tidal shoals and tidal channels on back-barrier BEBs in Portugal (Carrasco 551 et al., 2012). We suggest source and sink pathways associated with flood-tide delta 552 must be considered in BEB management.

\subsubsection{River and creek mouths}

554 BEBs in drowned river valleys (e.g., Pittwater) commonly have river or creek mouths 555 that drain through BEBs into the main estuary channel (Roy et al., 2001). BEBs 556 adjacent to river or creek mouths are highly dynamic as they are at the intersection of 557 fluvial and marine processes (Vila-Concejo et al., 2020). These BEBs present a range of decadal shoreline behaviours from prograding (e.g., Lady Robinsons north) through 559 to retreating (e.g., Great Mackerel) (Fig. 7a; Fig. 9e; Table 3). At Great Mackerel the 560 decadal retreating behaviour and slow recovery (up to 11 years) following the 1974 561 storms appears to be impacted by the alongshore migration of the creek mouth which 562 narrows beach widths (Fig. 1c; Fig. 6a; Fig. 10). Meanwhile, Gallop et al. (2020) and 563 Cowell (1989) point out that short-term BEB morphodynamics are equally impacted 564 by river or creek mouths, when BEBs lose more sand due to river and creek outputs.

565 Equally, BEBs located in low-lying settings (e.g., Kamay) on the front of sand spits and 566 prograded barriers (e.g., Lady Robinsons south) can represent retreating or relict 567 behaviours due to fluvial processes (Fig. 10). These BEBs can require anthropogenic 568 intervention to stabilise or mitigate BEB shorelines (Fig. 2; Fig. 8g), especially if 
shorelines are modified (e.g., Lady Robinsons south). Alternatively, BEBs can accrete

570 downdrift if alongshore sediment transport is the primary shoreline mechanism

571 (Nordstrom and Jackson, 2012). At Lady Robinsons north we suggest alongshore

572 transport, the northern river mouth and a retaining wall encourages the decadal

573 prograding behaviour (Fig. 2; Fig. 8d). Meanwhile, the variability of the dynamic

574 southern section could be attributed to the proximity to the Tucoerah River which may

575 supply sediment to prominent nearshore tidal shoals (see Fig. 8f). To understand BEB

576 shorelines near river and creek mouths we must consider that they are naturally

577 variable and are dynamic BEB shorelines due to interaction of fluvial, tidal and wave 578 forcing.

\subsection{Importance of anthropogenic interventions for BEBs}

580 BEBs in the same estuary often have different decadal shoreline behaviours (Fig. 10).

581 BEBs with the largest shoreline change are typically those with a history of 582 anthropogenic intervention, for example Currewol and Yarra bay were relict and post583 intervention are quasi-stable (Table 3). While at Lady Robinsons, reductions in beach 584 width are likely due to a sediment sink that developed following dredging in the 1970s 585 and 1990s for the Sydney Airport runways and the port navigation channel (Fig. 2; Fig. $5869 \mathrm{e}-\mathrm{g})$. Increases to estuary and bay water depth due to dredging, can destabilise 587 shorelines by modifying waves processes and redirecting swell energy to BEB 588 shorelines and by creating sediment sinks (Austin et al., 2018; Nordstrom, 1992); this 589 supports our retreating behaviour along central and south Lady Robinsons (Table 3). 590 In the Algarve (Portugal), Carrasco et al. (2012) notes that dredging of nearshore tidal 591 shoals and channels is the primary control for BEB shoreline retreat, even at locations 592 not exposed to swell waves. We suggest these factors contribute to retreating and 593 relict shoreline behaviours with important management implications. 
594 Anthropogenic interventions to counter decadal shoreline retreat in estuaries and bays 595 include groynes and revetments (Nordstrom and Jackson, 2012). This study and 596 others (Frost, 2011; Lowe and Kennedy, 2016) emphasise how groynes and sand 597 nourishment can mitigate the effects of repetitive storm erosion, alongshore sediment 598 transport, shoreline rotation and increased wave exposure on BEB shorelines 599 (Fig. 8a-b). For instance, at Lady Robinsons there are two examples of groyne 600 construction following bay dredging (Fig. 2; Table 3). Yarra Bay and Currewol both 601 display relict shorelines with a clockwise shoreline rotation following the construction 602 of the Port Botany revetment in the early 1970s and erosion from the 1974 storms. 603 This highlights how interventions change sediment supply or exposure for adjacent 604 BEBs (Fig. 2; Fig. 9a-b, e-g; Fig. 10). Nordstrom (1992) and Qiao et al. (2018) 605 emphasise how BEBs are vulnerable to anthropogenic interventions, with decadal 606 losses to BEB widths in Hong Kong and in the USA. We propose that swell energy 607 diverts, refracts and reflects on to the previously sheltered shorelines evident at Yarra 608 Bay and Currewol, which now both have a central groyne structure and quasi-stable 609 behaviours (Table 3). Furthermore, anthropogenic interventions to river and creek 610 mouths can cause retreating (Great Mackerel) and prograding (Lady Robinsons north) 611 behaviours (Fig. 2; Table 2), as shorelines readjust over decadal scales. Historically, 612 engineering interventions rarely considered BEB shorelines which in many cases 613 (e.g., Lady Robinsons, Yarra Bay) require subsequent intervention (groynes, sand 614 nourishment) to maintain the shorelines (Fig. 2; Table 3). Future anthropogenic 615 interventions must consider decadal BEB behaviours, to preclude future shoreline 616 retreat. 


\section{CONCLUSIONS}

618 We quantify and compare the decadal-scale behaviours of sandy shorelines in natural

619 and heavily modified estuaries. Through an assessment of 76 years of imagery (1941-

620 2017), we propose a behavioural typology of BEB decadal evolution including:

621 prograding, quasi-stable, retreating and relict shorelines. Prograding BEBs have

622 shorelines that migrate seaward, quasi-stable BEBs present minimal decadal change,

623 retreating and relict BEBs have shorelines that migrate landward with partial or no

624 recovery between storms, respectively. BEBs near the entrance of estuaries and bays

625 are typically swell exposed and quasi-stable. They recover at rates comparable to

626 open coast beaches (<3 years). In contrast, BEBs farther from the entrance exhibit

627 all four behaviours, are less swell exposed and when they recover do so at slower

628 rates (< 15 years) - that commonly exceed storm return timescales. Prograding BEBs

629 are typically away from the entrance, swell sheltered and controlled by other

630 processes including fluvial/tidal alongshore transport. BEBs adjacent to a flood-tide

631 delta can present quasi-stable and retreating behaviours depending on if the delta acts

632 as a sediment source or sink and this impacts recovery $(<3$ and $<11$ years

633 respectively). Decadal behaviours are the most variable on BEBs adjacent to river and

634 creek mouths due to the interaction of fluvial and marine processes, alongshore

635 transport and anthropogenic intervention (e.g., groynes and revetment, sand

636 nourishment, dredging). Dredging and land reclamation can lead to retreating and

637 relict shorelines if new sediment sinks are created and if wave energy is redirected

638 through dredged channels to previously protected BEBs. Meanwhile, groynes and

639 sand nourishment are measures that can be successful in creating quasi-stable BEB,

640 if interventions consider the altered wave or sediment conditions within a modified

641 estuary or bay. 


\section{ACKNOWLEDGEMENTS}

643 We acknowledge the traditional custodians of the Aboriginal lands on which this research was conducted. Thanks to the NSW Department of Planning, Industry and

645 Environment (DPIE) and the Newcastle Region Library for supplying historical aerial 646 images, to Manly Hydraulics Laboratory (DPIE) for supplying wave data, and to David

647 M. Kennedy from the University of Melbourne for Pittwater NearMap images. AVC and $648 \mathrm{JLL}$ are grateful for support received through the Partnership Collaboration Award linking the University of Sydney with University of California Davis.

\section{DATA AVAILABILITY}

651 The datasets reported in the paper are available from the corresponding author on reasonable request.

\section{REFERENCES}

Aijaz, S., Treloar, D., 2003. Beach management options at Lady Robinsons Beach, Botany Bay, Australia, Oceans 2003. Celebrating the Past ... Teaming Toward the Future (IEEE Cat. No.03CH37492), pp. 238-245 Vol.231.

Austin, T., Vila-Concejo, A., Short, A., Ranasinghe, R., 2018. A Multi-Scale Conceptual Model of Flood-Tide Delta Morphodynamics in Micro-Tidal Estuaries. Geosciences, 8(9), 324.

Australian Bureau of Meteorology, 2015. Stormy Weather: A century of storms, fire, flood and drough in New South Wales, Australian Government.

Birkemeier, W.A., Nicholls, R.J., Lee, G.-h., 1999. Storms, storm groups and nearshore morphologic change, Coastal Sediments. ASCE, pp. 1109-1122.

Boak, E.H., Turner, I.L., 2005. Shoreline Definition and Detection: A Review. Journal of Coastal Research, 688-703.

Bryant, E.A., Kidd, R., 1975. Beach erosion, May-June, 1974, Central and South Coast, NSW.

Carrasco, A.R., Ferreira, Ó., Matias, A., Freire, P., 2012. Natural and human-induced coastal dynamics at a back-barrier beach. Geomorphology, 159-160, 30-36.

Costas, S., Alejo, I., Vila-Concejo, A., Nombela, M.A., 2005. Persistence of storminduced morphology on a modal low-energy beach: A case study from NWIberian Peninsula. Marine Geology, 224(1-4), 43-56.

Cowell, P.J., 1989. Advisory Report on Management of Beach Erosion at Mackerel Beach. Coastal Protection Advisory Service.

Cowell, P.J., Kannane, A., 2000. Review of Changes to the Shores and Bed of Botany Bay: Past and Future.

Cowell, P.J., Nelson, H., 1991. Management of beach erosion due to low swell, inlet and greenhouse effects: Case study with computer modelling, 10th 

Zealand, pp. 311-315.

Davies, P.R.E., Mcllquham, J.D., 2011. Geotechnical design for the Port Botany expansion project, Sydney. Proceedings of the Institution of Civil Engineers Geotechnical Engineering, 164(3), 149-167.

Eulie, D.O., Walsh, J.P., Corbett, D.R., Mulligan, R.P., 2017. Temporal and Spatial Dynamics of Estuarine Shoreline Change in the Albemarle-Pamlico Estuarine System, North Carolina, USA. Estuaries and Coasts, 40(3), 741-757.

Foster, D.N., Gordon, A., Lawson, N., 1975. The Storms of May-June 1974, Sydney, NSW, Second Australian Conference on Coastal and Ocean Engineering, 1975: The Engineer, the Coast and the Ocean, The. Institution of Engineers, Australia, pp. 1.

Frost, G., 2011. Review of Coastal Processes and Evaluation of the Impact of the Constructed Groynes along Lady Robinsons Beach, Botany Bay, New South Wales, Australia. Bachelor of Environmental Science (Honours) https://ro.uow.edu.au/thsci/17, University of Wollongong, Wollongong, Australia.

Gallop, S.L., Vila-Concejo, A., Fellowes, T.E., Harley, M.D., Rahbani, M., Largier, J.L., 2020. Wave direction shift triggered severe erosion of beaches in estuaries and bays with limited post-storm recovery. Earth Surface Processes and Landforms, 45(15), 3854-3868.

Harley, M.D., 2017. Coastal Storm Detection. In: P. Ciavola, G. Coco (Eds.), Coastal Storms: Processes and Impacts. Wiley, Chichester, pp. 1-19.

Harley, M.D., Turner, I.L., Kinsela, M.A., Middleton, J.H., Mumford, P.J., Splinter, K.D., Phillips, M.S., Simmons, J.A., Hanslow, D.J., Short, A.D., 2017. Extreme coastal erosion enhanced by anomalous extratropical storm wave direction. Scientific Reports, 7(1), 6033.

Harley, M.D., Turner, I.L., Splinter, K.D., Phillips, M.S., Simmons, J.A., 2016. Beach response to Australian East Coast Lows: A comparison between the 2007 and 2015 events, Narrabeen-Collaroy Beach. Journal of Coastal Research, 388392.

Harris, D.L., Vila-Concejo, A., Austin, T., Benavente, J., 2020. Multi-scale morphodynamics of an estuarine beach adjacent to a flood-tide delta: Assessing decadal scale erosion. Estuarine, Coastal and Shelf Science, 106759.

Jackson, N.L., 1995. Wind and Waves: Influence of Local and Non-local Waves on Mesoscale Beach Behavior in Estuarine Environments. Annals of the Association of American Geographers, 85(1), 21-37.

Jones, G., 1981. Effects of dredging and reclamation on the sediments of Botany Bay. Australian Journal of Marine and Freshwater Research, 32, 369-377.

Kennedy, D.M., 2002. Estuarine Beach Morphology in Microtidal Middle Harbour, Sydney. Australian Geographical Studies, 40(2), 231-240.

Komar, P.D., 1998. Beach Processes and Sedimentation. Prentice Hall.

Kulmar, M., Gordon, A., 1987. Coastal Processes of the Pittwater North Western Foreshores, Eighth Australasian Conference on Coastal and Ocean Engineering, 1987: Preprints of Papers. Institution of Engineers, Australia, pp. 109.

Lowe, M.K., Kennedy, D.M., 2016. Stability of artificial beaches in Port Phillip Bay, Victoria, Australia. Journal of Coastal Research, 75(sp1), 253-257, 255. 
Nordstrom, K.F., 1992. Estuarine Beaches: An introduction to the physical and human factors affecting use and management of beaches in estuaries, lagoons, bays and fjords. Springer Netherlands.

Nordstrom, K.F., Jackson, N.L., 2012. Physical processes and landforms on beaches in short fetch environments in estuaries, small lakes and reservoirs: A review. Earth-Science Reviews, 111(1), 232-247.

Novak, K., 1992. Rectification of digital imagery. Photogrammetric engineering and remote sensing, 58, 339-339.

OEH, 2018. Estuaries of NSW. Office of Environment and Heritage.

Qiao, G., Mi, H., Wang, W., Tong, X., Li, Z., Li, T., Liu, S., Hong, Y., 2018. 55-year (1960-2015) spatiotemporal shoreline change analysis using historical DISP and Landsat time series data in Shanghai. International Journal of Applied Earth Observation and Geoinformation, 68, 238-251.

Rocchini, D., Metz, M., Frigeri, A., Delucchi, L., Marcantonio, M., Neteler, M., 2012. Robust rectification of aerial photographs in an open source environment. Computers \& Geosciences, 39, 145-151.

Roy, P.S., Williams, R.J., Jones, A.R., Yassini, I., Gibbs, P.J., Coates, B., West, R.J., Scanes, P.R., Hudson, J.P., Nichol, S., 2001. Structure and Function of Southeast Australian Estuaries. Estuarine, Coastal and Shelf Science, 53(3), 351384.

Ruggiero, P., Kaminsky, G.M., Gelfenbaum, G., 2003. Linking proxy-based and datum-based shorelines on a high-energy coastline: implications for shoreline change analyses. Journal of Coastal Research, 57-82.

Shand, T., Goodwin, I., Mole, M., Carley, J., Browning, S., Coghlan, I., Harley, M., Preston, W., 2010. NSW coastal inundation hazard study: coastal storms and extreme waves.

Short, A., Trenaman, N., 1992. Wave climate of the Sydney region, an energetic and highly variable ocean wave regime. Marine and Freshwater Research, 43(4), 765-791.

Short, A.D., 1993. Beaches of the New South Wales Coast; a guide to their nature, characteristics, surf and safety. Sydney University Press, Sydney.

Vila-Concejo, A., Austin, T.P., Harris, D.L., Hughes, M.G., Short, A.D., Ranasinghe, R., 2011. Estuarine beach evolution in relation to a flood-tide delta. Journal of Coastal Research, 190-194.

Vila-Concejo, A., Gallop, S.L., Largier, J.L., 2020. Sandy beaches in estuaries and bays. In: D.W.T. Jackson, A.D. Short (Eds.), Sandy Beach Morphodynamics. Elsevier, London.

Vila-Concejo, A., Hughes, M.G., Short, A.D., Ranasinghe, R., 2010. Estuarine shoreline processes in a dynamic low-energy system. Ocean Dynamics, 60(2), 285-298.

Vila-Concejo, A., Short, A., Hughes, M., Ranasinghe, R., 2007. Flood-tide delta morphodynamics and management implications, Port Stephens, Australia. Journal of Coastal Research, 50, 705-709.

Wilson, K.M., Power, H.E., 2018a. Seamless bathymetry and topography dataset for Botany at $10 \mathrm{~m}$ gridsize. PANGAEA.

Wilson, K.M., Power, H.E., 2018b. Seamless bathymetry and topography dataset for Hawkesbury River at 50m gridsize. PANGAEA.

Wilson, K.M., Power, H.E., 2018c. Seamless bathymetry and topography dataset for Sydney Harbour (Port Jackson) at 10m gridsize. PANGAEA. 